\title{
SEMINARIO DE HISTORIA
}

Dpto. de $\mathrm{H}^{\mathrm{a}}$ del Pensamiento y de los Movs. Sociales y Políticos, Universidad Complutense de Madrid Fundación José Ortega y Gasset

Curso 2010-2011

Documento de trabajo 2010/7

\section{ORÍGENES MITOLÓGICOS DE ESPAÑA}

\author{
JOSÉ ÁLVAREZ JUNCO \\ GREGORIO DE LA FUENTE MONGE \\ Universidad Complutense de Madrid
}

SESIÓN: JUEVES, 4 DE NOVIEMBRE DE 2010, 19 H.

Lugar: Aula 1

Instituto Universitario José Ortega y Gasset

c/ Fortuny 53, 28010 Madrid

Contacto: seminariodehistoria@gmail.com 


\section{Orígenes mitológicos de España \\ José Álvarez Junco \\ Gregorio de la Fuente Monge}

\section{Primeras referencias a Iberia o Hispania: Vinculación con dioses y héroes mitológicos}

El etnocentrismo es un fenómeno habitual en las sociedades humanas. Lo cual no sólo significa considerarse centro del mundo sino "normales" o naturales, como se deduce del término reservado a los demás: "excéntricos", fuera del centro y, a la vez, de comportamiento "raro". Es una tendencia difícil de combatir pero no resiste, en sí misma, el menor análisis lógico, ya que el mapa del mundo, por ser la superficie de una esfera, no puede tener centro. Si referimos lo "central" a lo relacionado con las grandes civilizaciones, que sin duda han marcado las pautas de conducta dominantes, en el caso de la Península Ibérica hay que reconocer que, a lo largo de los primeros milenios de la historia, ha estado muy lejos del centro. Basta imaginar un mapa del mundo conocido hasta hace 500 años. En él la Península Ibérica era un apéndice situado en el extremo occidental, un Finis Terrae, según el término latino, confín del Mar Tenebroso. Ni existió en este rincón del planeta una gran civilización propia ni sus habitantes tuvieron contacto con las grandes civilizaciones, hasta la llegada de fenicios y griegos.

De ahí que fuera lugar de leyenda, escenario ideal para relatos mitológicos. Hasta aquel fin del mundo llevó la imaginación griega a Hércules y allí situó dos de sus "trabajos" o hazañas: en Tartessos venció a Gerión, hijo del rey ganadero Crisaor, y robó sus bueyes; y en las Hespérides conoció a Atlas y sostuvo el cielo sobre sus hombros mientras éste recogía las manzanas de oro. También cerró, en el Estrecho de Gibraltar, el Mediterráneo con sus dos enormes columnas. Iberia era, pues, tierra lejana y prodigiosa, umbral de aquella Atlántida naufragada que Platón situaba en medio del océano. Y Cádiz, Gádir o Gades marcaba el hito terminal del mundo.

Entrando en la era histórica, la de los datos avalados por documentos, las referencias a Iberia por parte de autores griegos, y más tarde romanos, crecen de manera sustancial a medida que se avanza desde el siglo VII hasta el I a. C. Para nuestro tema interesa especialmente Trogo Pompeyo, autor de unas Historiae Philippicae, que sólo conocemos a través de un resumen de Justino, del siglo II. Se menciona allí a un rey Hispalo o Hispano, también llamado luego Ibero, una especie de héroe-fundador, como Rómulo o Eneas, sin el menor fundamento histórico, pero importante para la creación de una identidad, pues se suponía que había dado nombre a la Península. Previamente, Herodoto se había referido a Argantonio, rey de Tartessos. A ambos harán referencias, mucho más tarde, san Isidoro, Jiménez de Rada o Alfonso X; pero sin renunciar al dato mitológico previo, con el que lo combinaron, pues hicieron de Hispano sobrino de Hércules, a quien éste habría legado el trono de Hispania. Estos dos nombres -el de Hispano a veces desdoblado en dos o tres- se convertirían en referencia habitual tras su inclusión en la lista de reyes inventada por Annio de Viterbo, de quien hablaremos. 
Trogo Pompeyo también parece haber sido el origen de otros nombres legendarios: los de dos reyes de Tartessos, Gárgoris y Habis, o Habidis. El segundo de los cuales era hijo del primero y de la más hermosa de sus hijas; para encubrir el incesto, Gárgoris abandonó al recién nacido en el bosque, donde fue criado por las alimañas. Reapareció años más tarde, como adolescente, y Gárgoris lo reconoció como hijo/nieto y sucesor suyo. Fue un monarca sabio, gran legislador y enseñó a su pueblo a uncir los bueyes a la reja. El mito tiene muchos antecedentes, entre otros el de Aristeo, hijo de Apolo y de la ninfa Cirene, fundador legendario de Tebas que enseñó a sus súbditos el cultivo de las abejas y el cuidado de las viñas. Ha sido a veces interpretado como una representación del paso de la economía cazadora/recolectora a la agrícola/ganadera, o del monarca arbitrario y tiránico al rey legislador.

\section{Patriarcas bíblicos y fundadores del cristianismo}

Al iniciarse la era cristiana, el historiador Flavio Josefo lanzó una leyenda destinada a tener éxito muy duradero. Según ella, tras el fracaso de la Torre de Babel y la aparición, como castigo divino, de las distintas lenguas humanas, los descendientes de Noé se dividieron en 72 familias o gentes. Una de ellas fue la de Túbal, quinto hijo de Jafet, que se asentó en Hispania y fue por tanto el padre de los hispani o españoles: "Thubal, a quo iberi, qui et Hispani”. El dato sería recogido por san Jerónimo, que lo trasmitió a Isidoro de Sevilla y tras él a múltiples historiadores hasta llegar nada menos que al siglo XIX. De Túbal se derivarían nombres como Setúbal o Tudela. El tubalismo sería reavivado por el vasquismo, como veremos.

Mucho más importante que Túbal fue la leyenda de Covadonga. La batalla de este nombre tuvo lugar, en principio, en la segunda década del siglo VIII. Pero hay que tener en cuenta que, tras la caída de los visigodos, apenas hay crónica alguna hasta llegar al ciclo de Alfonso III, a finales del IX. Solamente se pueden mencionar dos, elaboradas por mozárabes cordobeses o toledanos. La más temprana, del 741, narra la invasión musulmana de treinta años antes de forma breve y aséptica ("In Occidentis quoque partibus regnum Gothorum, antiqua solidiate firmatum apud Spanias, per ducem sui exercitus nomine Muza adgressus, edomuit, et regno abiecto uectigales facit"). En tono muy distinto, la crónica siguiente, del 754, está dominada por el catastrofismo y recurre a todos los ejemplos bíblicos e históricos (Troya, Jerusalén, Babilonia o Roma) para explicar lo ocurrido en la infelix Spania, antaño deliciosa y hoy miserable ("quondam deliciosa et nunc misera effecta"). Ninguna de ellas se refiere a núcleos rebeldes. Habrá que esperar ciento treinta años, hasta los 880, para encontrar otras crónicas cristianas, y éstas emanan ya del foco asturiano.

Por parte musulmana, tampoco abundan las crónicas históricas antes del siglo X, en que el califato de Córdoba vivió su momento de esplendor. Las primeras narraciones de la conquista proceden de los círculos malikíes egipcios y los relatos históricos se derivaron de los ajbar que, versando inicialmente sobre la vida del Profeta, acabaron reseñando tradiciones y cualquier hecho que creían digno de ser recordado, entre los que no incluyeron batallas libradas en Asturias. En conjunto, pues, la larga etapa que se desarrolla entre finales del siglo VII y finales del IX constituye, como dice Eduardo Manzano, "uno de los períodos de mayor escasez de fuentes de nuestra era". Y fue justamente en esos doscientos años brumosos donde se sitúan hechos de importancia 
decisiva para la mitología nacionalista posterior, como la invasión musulmana, el inicio de la resistencia por don Pelayo en Covadonga o el descubrimiento de la tumba del apóstol Santiago en el Campus Stellae. Sobre todos ellos tenemos que manejarnos con fuentes muy posteriores, que los relatan en términos legendarios y casi indescifrables.

Las historias escritas en el principal de los centros norteños no sometidos al poder musulmán fueron obra de monjes u obispos muy ligados a la corte de Alfonso III (866-910), monarca que había consolidado y expandido el hasta entonces modesto reino asturiano por el valle del Duero. Era el momento de legitimar aquella pujante monarquía, y era también la ocasión para que el obispado de Oviedo reclamara la primacía frente a los todavía poderosos rivales mozárabes de Toledo y Córdoba (y frente a la emergente Iria Flavia). La corte de Alfonso III, apoyándose en monjes y obispos, emprendió, pues, lo que J. A. García de Cortázar llama una "tarea deliberada de creación de una memoria histórica". Y una parte esencial de esta tarea fue la leyenda sobre Covadonga, batalla fundacional que iniciaba el ciclo bélico contra el dominio musulmán y en la que los cristianos habrían vencido con el apoyo divino. Además de ser de sangre real, como veremos luego, Pelayo ganó una primera y gran batalla sobre un número abrumador de infieles con manifiesto auxilio de la Virgen María, a la que invocó antes de iniciar su desigual combate. Lo cual demostraba que tanto él como sus sucesores eran los defensores de la verdadera fe y habían restablecido la alianza con Dios rota por los últimos reinados godos.

Para describir aquel primer enfrentamiento bélico con los musulmanes, los cronistas -que escribían, recordemos, casi dos siglos más tarde- recurrieron a los modelos narrativos bíblicos y a los de la Antigüedad clásica, únicos cánones que tenían a su disposición. De esta última tomaron, según Guillermo García Pérez, una conocida leyenda, procedente de las guerras médicas: el año 480 a. C., un ejército de varios cientos de miles de hombres enviado por Jerjes había invadido Grecia y devastado ciudades hasta que se encontró ante el santuario de Apolo en la montaña de Delfos; los pocos centenares de defensores griegos en él refugiados consultaron al oráculo sobre la protección de los tesoros sagrados y el dios les respondió que él mismo se bastaba para protegerlos; en efecto, al comenzar la batalla salieron del santuario rayos y se desprendieron de la montaña peñascos que se precipitaron sobre los despavoridos soldados persas; en medio de la confusión, éstos comenzaron a darse muerte unos a otros; finalmente, los pocos miles de sobrevivientes que huían aterrorizados perecieron, víctimas de un fuerte temblor de tierra y el desbordamiento de un río. El relato de Covadonga reproducía este esquema casi al pie de la letra.

La coincidencia con relatos bíblicos es también sugestiva. Como ha señalado Javier Zabalo, tanto la Rotense como la Ad Sebastianum cifran en el número exacto de 187.000 los musulmanes muertos (a los que llaman "paganos" o "caldeos", para mayor sabor bíblico), que exagera sólo levemente el de los asirios aniquilados por el Ángel del Señor cuando el rey Senaquerib quiso atacar Jerusalén (185.000). De esos 187.000, dos tercios -124.000- murieron en la batalla principal, en el intento de asalto a la gruta de Covadonga, una cifra que es, de nuevo, casi coincidente con la de los 120.000 madianitas que perecieron ante Gedeón, los 120.000 infantes enviados contra Judea por Nabucodonosor bajo el mando de Holofernes, igualmente aniquilados, o los 120.000 enemigos a los que derrotó Judas Macabeo con sólo 6.000 hombres. El resto, 63.000, son los que perecieron en la huída, al derrumbarse un monte o desbordarse enfurecidamente el río Deva, según las versiones. De esa forma, concluye Zabalo, don 
Pelayo quedaba implícitamente equiparado a Gedeón y Judas Macabeo y los hispanogodos se ponían al nivel del Pueblo Elegido en cuanto a protección divina.

Un tercer mito religioso acabaría por ser mucho más importante que Túbal e incluso que Covadonga: Santiago apóstol, de quien se extendió la leyenda de que había predicado el cristianismo en Hispania e incluso, en un momento de desfallecimiento, había sido reconfortado por la Virgen María, que se le apareció sobre un pilar en Zaragoza.

Los datos históricos que poseemos (los Hechos de los Apóstoles) presentan a Santiago el Mayor como el primero de los Apóstoles de Cristo en morir, ejecutado por Herodes Agripa el año 44 d. C. Que en poco más de diez años hubiera viajado al otro extremo del Mediterráneo, desarrollado una labor misionera, con tiempo suficiente para sentirse fracasado y sobreponerse, hubiera regresado a Jerusalén, muerto allí y pese a todo estuviera enterrado en Galicia, era poco verosímil. Hasta el siglo IX, de hecho, no era ésa la tradición más extendida entre los cristianos españoles. Por el contrario, habrían sido siete obispos enviados por los Apóstoles desde Roma, cuyo primer éxito tuvo lugar en Acci (Guadix), donde se presentaron en el curso de una fiesta pagana; expulsados y acosados por los iracundos celebrantes, huyeron de la ciudad por un puente que, al paso de sus perseguidores, se hundió. Tras esta señal divina, se produjo una conversión masiva en la zona, a partir de la cual se extendió la fundación de iglesias en la Península. Bajo Alfonso II, sin embargo, aparecieron luces nocturnas en Iria Flavia, y se encontró allí una tumba que se dijo era de Santiago. Pese a su éxito popular, tardó más de dos siglos en ser aceptado. Las crónicas del ciclo de Alfonso III ni registran el dato. Como escribe Juan Gil Fernández, "la clerecía ovetense debió de ver con enorme recelo los balbuceos del culto jacobeo" porque "Iria/Compostela, enriquecida con las reliquias del apóstol, podía aspirar a convertirse, como de hecho hizo, en cabeza de la cristiandad hispana". No menos recelaron los clérigos toledanos, que incluso bajo dominio musulmán aspiraban a la primacía peninsular por haber sido la capital visigoda. Y tampoco simpatizaba con el hallazgo el clero romano, celoso defensor de su superioridad, derivada en buena parte de albergar el único cuerpo entero de un apóstol conservado.

Pero las circunstancias políticas de finales del siglo XI hicieron posible la aceptación del milagro. Tras dos poderosos reinados (Sancho el Mayor de Navarra y Fernando II de León), que expandieron los dominios cristianos a todo el tercio norte peninsular, llegó Alfonso VI, monarca castellano que emprendió una política de alianzas con la casa de Borgoña y la orden de Cluny, empeñada entonces en una pugna con Roma para reformar la laxitud de la vida monástica. Uno de sus colaboradores en esta política fue Diego Gelmírez, clérigo inteligente y ambicioso, secretario de Raimundo de Borgoña, uno de los dos yernos franceses de Alfonso VI. Los cluniacenses comprendieron que el cuerpo atribuido a Santiago podía ser un excelente instrumento para, por un lado, reforzar la guerra contra el Islam en la Península Ibérica y, por otro, rebajar las ínfulas papales. La ruta jacobea fue lanzada desde Saint Jacques de París y fue llamada "el camino francés". Ya en los años 1120, Calixto II, papa borgoñón, sancionó el Liber Sancti Jacobi, o Codex Calixtinus y estableció los Años Jacobeos y las indulgencias por el peregrinaje. Gelmírez ocupó la sede de Santiago, convertida ahora en arzobispado, y dos franceses ocuparon sucesivamente la sede de Toledo, recién reconquistada por Alfonso VI. Los yernos franceses de este rey se 
convertirían en herederos suyos -reyes de Castilla y Portugal respectivamente- tras la muerte de su único hijo varón en Uclés.

Más interesante que todo esto es la conversión de Santiago, hasta entonces pacífico pescador galileo, en belicoso jinete que aparecía personalmente en batallas decisivas cortando cabezas de musulmanes. Américo Castro puso en conexión esta aparición del Santiago guerrero con el lanzamiento de la idea de cruzada, respuesta cristiana a la yihad o guerra santa musulmana. El cristianismo, doctrina originariamente pacifista, había planteado graves problemas morales a sus primeros prosélitos para poder servir en las legiones romanas; el papa León I salió al encuentro de Atila, que se acercaba amenazadoramente a Roma, sin armas. Pero a partir de san Agustín se fue elaborando el concepto de "guerra justa", que Santo Tomás hizo suyo. El cambio definitivo a guerra santa se produjo con la prédica de la primera cruzada por Urbano VI (1095, justamente durante el reinado de Alfonso VI), que convertía a aquellos combatientes en "soldados de Cristo". En el caso español, la guerra contra los musulmanes, legitimada hasta entonces por la recuperación del reino visigodo (guerra, por tanto, "justa"), pasa a ser con Santiago guerra "santa" (o refuerza este aspecto, ya iniciado con el mito de Covadonga, a finales del IX).

Desde el punto de vista de la construcción identitaria, lo importante de Santiago es que se convierte en símbolo (bélico) de España. Santiago mataba moros por "España", los reyes de Castilla y León se proclamaron "alféreces de Santiago" y los gritos de combate fueron “¡Santiago y cierra España!” o “¡Santiago y a ellos!”.

Portugal, como parte de "Espanha" que era (concepto geográfico, no político), participó de este culto a Santiago, aparecido por ejemplo en la conquista de Coimbra. Solamente tras la batalla de Aljubarrota (1385), que puso fin a un ciclo de guerras con Castilla y asentó a la dinastía de Avis, cambiaron de santo patrón. En esa batalla, los ingleses, aliados de los portugueses, llevaban a Saint George como protector. Como en el lado enemigo se invocaba a Santiago, los portugueses se acogieron al santo inglés. Ante el éxito, y para distanciarse de Castilla, cambiaron de protector.

En el monasterio de Alcobaça (erigido precisamente para recordar la "Batalha"), en el siglo XV, se añadió un elemento más, que convertía en divino el origen mismo del reino de Portugal. Fue el llamado "milagro de Ourique". En la noche anterior a otra batalla, en la que don Afonso Henriques, conde entonces de Portugal, derrotó a un ejército de cinco reyes musulmanes y les arrebató la ciudad de Ourique (1139), se le apareció Jesucristo en persona mostrándole sus llagas y asegurándole que, si portaba la cruz, triunfaría al día siguiente, pese a la inferioridad numérica de sus tropas; le recomendaba a la vez que aceptase la corona de Portugal que le ofrecerían a continuación. De ahí vienen los cinco puntos rojos que hoy figuran en el escudo de Portugal (las llagas de Cristo; o los cinco reyes musulmanes). Significativamente, todo ello ocurrió un 25 de julio, lo que indica que el relato se mantenía dentro del marco de la mitología santiaguista. El modelo es obviamente el sueño de Constantino en la noche anterior a su victoria sobre Majencio en el Puente Milvio, cuando Cristo se le apareció con la cruz diciéndole "In hoc signo vinces". La protección divina sobre Portugal se elevaba así al mismo nivel que la disfrutada por los emperadores cristianos.

Tampoco bastó con eso. Fernâo de Oliveira, en el siglo XVI, añadió una bula papal que ratificaba la concesión del título de rey de Portugal a cambio de su 
subordinación vasallática a Roma. Tal documento se presentaba con valor jurídico de "constituiçâo" portuguesa, por cuando "al principal lhe deu ser e constituiu por autoridade divina, como antigamente os profetas e sacerdotes faziam quando ungiam os reis, e agora fazem quando ungem os imperadores; [...] o esencial é que o poder dos reis venha de Xristo por meio dos sumos pontífices, seus vigários".

\section{Guerreros y caudillos legendarios en la Edad Media castellana}

A lo largo de toda la Edad Media y los dos primeros siglos de la moderna, los reinos cristianos de la Península desarrollaron una serie de relatos míticos cuyo principal objetivo era anclar su legitimidad en antecedentes gloriosos y de la máxima antigüedad. La conexión con el mundo de lo sobrenatural se fue combinando con vinculaciones con héroes o personajes fabulosos, con guerreros o caudillos legendarios o con pueblos o reinos de tiempos pretéritos. El caso de mayor éxito fue el mito gótico, al que apeló el reino de Asturias, posteriormente de Galicia, León y Castilla, eje principal de la futura España.

El inicio de todo fue, como sabemos, el ciclo cronístico ligado a Alfonso III. De las tres crónicas alfonsinas - una de ellas con dos versiones-, la más valiosa es quizás la Crónica Albeldense, que inserta el reino astur en una historia de proyección universal, con los monarcas asturianos siguiendo a los godos y éstos a los emperadores romanos. Se menciona en ella por primera vez a Pelayo, primer rey asturiano, vencedor en una batalla, sin nombre aún, en la que "fue devuelta su libertad al pueblo cristiano y nació, por providencia divina, el reino de Asturias". Pero el mayor espacio se dedica a Alfonso II (791-842), verdadero fundador del reino, que hizo de Oviedo la capital, dejó de pagar tributos a Córdoba y, a la vez que adoptaba el ceremonial godo en iglesias y palacios, aprovechó la querella "adopcionista" para romper con Toledo como cabeza de la Iglesia hispana (para lo cual se erigió en defensor de la ortodoxia papal, apoyando al Beato de Liébana frente a Elipando, obispo mozárabe de Toledo). Es importante anotar que ninguno de los cronistas asturianos del momento llega a hacer una historia de España tan integradora como la que escribe al-Razi en la Córdoba califal; la "Hispania" del momento es al Andalus. Pero la corte asturiana revela ya sus ambiciones. No sólo buscan legitimar el reino encabezado en ese momento por Alfonso III constatando la protección providencial sobre la lucha iniciada en Covadonga sino que articulan su relato alrededor del mito goticista o neo-goticista.

Tal mito consistía en entroncar el reino asturiano con el visigodo de Toledo. Para lo cual los cronistas necesitaron emparentar a don Pelayo con la casa real goda. Y lo hicieron de diversas maneras: como simple spatarium de Vitiza y Rodrigo, según una mención de la Rotense; como hijo del duque Favila, "de linaje real", según la Ovetense o Ad Sebastianum; como hijo de Bermudo y nieto de Rodrigo, para la Albeldense; e incluso como primo de don Opas, según otra mención de la Rotense, detalle este último desafortunado y destinado al olvido, por tratarse de la traidora familia de Vitiza. La Albeldense también hizo de Alfonso I, yerno y segundo sucesor de Pelayo, hijo de un duque de Cantabria que descendía de Leovigildo y Recaredo. Se subrayaba así la legalidad sucesoria de los reyes asturianos. Todo ello es poco verosímil pero, tratándose de un mito, no importa tanto que respondiera a una realidad como que fuera aceptado, cosa que sin duda logró. 
Además de asentar la legitimidad de los reyes astures sobre su conexión hereditaria con la monarquía visigoda, era preciso subrayar la de ésta última en sí misma, frente al carácter "intruso" del régimen musulmán. De ahí que esos cronistas que hablan en términos tan negativos de la "ocupación" o "invasión" musulmana el 711, se refieran candorosamente a la "entrada" o "emigración" de los visigodos trescientos años antes. Planteamiento que tenía un evidente propósito político y que tendió a ser asumido por todos los núcleos cristianos del norte. Pues ello no sólo justificaba su existencia -y creaba, quisieran o no, un lazo común entre ellos-, sino que legitimaba su lucha, cuyo fin era "restaurar" el dominio godo y por tanto no se detendría hasta que toda Hispania, todo el territorio peninsular, se viera libre de los "invasores" agarenos. No se utiliza aún el término Reconquista, que es muy tardío (finales del XVIII, inicios del XIX), pero la idea está presente desde estas crónicas de finales del siglo VIII.

Puesto que lo fundamental era entroncarse con el reino godo, era lógico que las crónicas se llamaran Gothorum, no Hispanorum o Hispaniarum; la Albeldense tiene incluso un epígrafe titulado "Serie de los reyes godos de Oviedo" (Ordo Gothorum Obetensium Regum). Pero lo que se había hundido con la invasión sarracena no era sólo el reino godo. La misma Albeldense pone en boca de Pelayo la intención de devolver la libertad al pueblo "cristiano" y en otros momentos se habla de "la Iglesia del Señor" o de la "restauración de la Iglesia, del pueblo y del reino". También se habla de la "pérdida de Hispania" y don Pelayo dice, en su diálogo con el obispo traidor Opas, que la montaña de Covadonga será la "salvación de Hispania y la reparación del ejército del pueblo godo" (per istum modicum monticulum quem conspicis sit Spanie salus et Gotorum gentis exercitus reparatus). Un tema éste, el de la "pérdida de España", que con el transcurso del tiempo habría de convertirse en eje central del discurso. En ese momento, por tanto, el sujeto principal, cuya vida había sido injustamente extinguida y se estaba intentando restablecer, era ambiguo: lo godo, ante todo; lo cristiano, casi al mismo nivel; y sólo en un tercer escalón, un tanto retórico, lo hispano.

Al defender el goticismo, los cronistas eclesiásticos revelaban una segunda intención política: el deseo de la Iglesia católica de recuperar la privilegiada participación en el sistema de poder de que había disfrutado tras el pacto con Recaredo el 589. Porque, a partir de aquel año, se había instaurado una organización cercana al teocratismo, con un monarca elegido en los concilios de Toledo que, al ser consagrado por la Iglesia, regía en nombre de Dios, según explicó san Leandro. Pedir, por tanto, que se restaurara la monarquía goda era una forma de pedir que la Iglesia recuperara su poder perdido. Aquella alianza entre la Iglesia y el Estado se estaba reconstruyendo ya en el nuevo reino astur, a juzgar por las noticias de la Albeldense de que Ramiro I (842$850)$ "terminó con los magos", es decir, que combatió los cultos paganos, y que bajo Alfonso III "ecclesia crescit et regnum ampliatur". La nostalgia por recuperar la situación de los últimos decenios godos había sido expresada ya en el siglo VIII por Eulogio de Córdoba, en un Memoriale Sanctorum en el que recriminaba al obispo mozárabe de su ciudad que conservara el culto católico "en beneficio de la gente impía a cuyo poder ha pasado el cetro de Hispania por nuestra maldad después de la ruina y destrucción del reino de los godos, cuando la Iglesia crecía en el felicísimo cultivo de la fe cristiana". "Felicísimo" era, sin duda, el adjetivo que merecía aquel período, único hasta el momento en que Hispania había estado sometida a un solo poder monárquico, independiente y, además, católico. Eso explicaría lo que Matesanz ha llamado su "larga perduración en el imaginario historiográfico". 
Esta idealización de la situación política anterior al 711 planteaba, sin embargo, un grave problema lógico para historiadores que se movían dentro de un marco explicativo providencialista: cómo explicar el colapso godo. ¿Por qué permitió la divina providencia el desmoronamiento de aquella "felicísima" situación? No era fácil entender el enojo divino con aquella monarquía cuando, tras doscientos años de empecinamiento en el "error arriano", había abjurado de la herejía y se había alineado con los defensores de la verdadera fe. Pero aquellos clérigos no podían salir del universo mental bíblico y lo ocurrido tenía que explicarse como un castigo providencial, al igual que las derrotas del Pueblo Elegido ante sus vecinos gentiles cuando caía en la idolatría o desobedecía a Jehovah. Así habían resuelto los historiadores cristianos, a partir de una idea de Agustín de Hipona, el cataclismo del imperio romano, que planteaba un problema similar: todo se había debido a los vicios de los últimos emperadores, pese a haberse convertido al cristianismo. Y es lo que repiten las crónicas alfonsinas de finales del IX. En la Crónica Profética se lee que Dios había abandonado a los godos "porque no hicieron una penitencia digna de sus pecados y porque abandonaron los preceptos del Señor y las instituciones de los sagrados cánones"; se referían sobre todo a la política de Vitiza, rey que rompió, según se deduce de estos textos, el pacto con la jerarquía eclesiástica, pues no sólo se le acusa de haber tenido varias esposas y concubinas sino de haber disuelto el sistema de concilios e incluso intentado imponer el matrimonio a los clérigos.

Un mal reinado parece un motivo nimio si se piensa en la magnitud del castigo, nada menos que la liquidación definitiva de la monarquía goda y sometimiento de Hispania al yugo infiel durante ocho siglos. Pero en la imaginación de aquellos cronistas no cabían otras causas. Con el paso de los siglos se le añadiría algún otro reinado godo poco ejemplar e incluso se generalizaría la degradación hasta convertirse en tópica la "molicie" visigoda (un término, "molicie", aplicado también a los momentos finales del imperio romano). Pero como ejemplos solamente se aportaban los pecados de uno o dos reyes, a los que se añadió como detonante o pretexto inmediato el estupro de "la Cava", la hija del conde don Julián, cometido por el rey Rodrigo (o el propio Vitiza, según las versiones), lo que hizo que el conde traidor marchara a tierra infiel y solicitara la ayuda de Tarik y Muza, o que los hijos de Vitiza se pasaran al enemigo en plena batalla de Guadalete.

Otro problema relacionado con el mito goticista es el que plantearon hace años A. Barbero y M. Vigil: que era ilógica la adopción de "la tradición gótica como ideología oficial" en un núcleo de poder que surgía "en unas regiones no dominadas por los visigodos, ni asimiladas dentro de las estructuras del reino de Toledo". Porque el neo-goticismo de los cronistas del siglo IX suponía negar la situación de marginalidad respecto del resto de la Península vivida por la región montañosa cántabro-astur bajo romanos y visigodos y negar, sobre todo, cualquier continuidad entre esa marginalidad y la emergencia de un núcleo rebelde frente a los musulmanes. Al revés que los historiadores godos, que habían anclado la legitimidad de su monarquía en la del imperio romano o la del bizantino, e incluso al revés que los cronistas de los califas cordobeses, que también añadieron los nombres de sus soberanos a las dos listas anteriores, los clérigos que rodeaban a Alfonso III apenas buscaron antecesores a este nuevo poder más allá de los visigodos. Atribuyeron, así, a este núcleo insumiso el título de sucesor oficial de un reino toledano y de una cultura en los que, en realidad, no había 
estado integrado, como demostraban su independencia política práctica y la persistencia de cultos pre-cristianos y estructuras sociales gentilicias.

La tesis de Barbero y Vigil tuvo gran éxito en su momento, aunque más tarde haya tendido a verse desmentida por parte de autores como Armando Besga, que subrayan la existencia de importantes pruebas de la romanización e integración en el poder visigodo entre los pueblos del norte, e incluso por la fuerte emigración y refugio de parte de la nobleza y la jerarquía eclesiástica visigoda tras el 711 detectada por Yves Bonnaz. Tampoco parece lógico que, siendo el reino asturiano un mero continuador de la marginalidad de aquella zona norteña, mostrara tanto empeño en expandirse por los terrenos del sur.

El siguiente mito guerrero que dominó la Edad Media fue el del Cid Campeador. Su historia se sitúa mucho más tarde, en la segunda mitad del siglo XI, pero apenas hubo crónicas en el lapso intermedio (y El Cid, además, no legitimaba a Asturias, Galicia o León, sino a Castilla, creación posterior). Desde finales del IX, en que se escribieron las crónicas alfonsinas, la escasez de fuentes obliga a dar un salto de cien años hasta finales del X, época en la que se datan el Cronicón Sampiri, el Iriense y, según parece, la crónica mozárabe Pseudo-Isidoriana; y otro siglo más habrá de transcurrir para que, a finales del XI y comienzos del XII, aparezcan el Cronicón Complutense (1065), el Ovetense o de Pelayo (c. 1109) y el Silense (1115-18). Son relatos de reinos y batallas, de menor importancia que los textos alfonsinos, y dan por supuesta la conexión gótico-asturiana. En ninguno de ellos se menciona al Cid, ni siquiera en la Ovetense, que narra con detalle el reinado de Alfonso VI.

El Cid Campeador aparece mencionado a mediados del XII en la Dajira de Alí Abenbasam, "El tesoro de las bellas cualidades de la gente española", escrita como "queja de la importancia que aquí se daba a lo de afuera, con desdén de lo propio". En ella se exaltan las glorias de al-Andalus, en especial en el terreno de la poesía, y sus personajes son unos extranjeros llegados a estas tierras y unos afroasiáticos que nunca pasaron por ellas; incluso por El Cid siente orgullo el autor, pues, aunque cruel y desleal, fue "uno de los milagros del Señor [...] por su amor a la gloria, por la prudente firmeza de su carácter y por su valor heroico". En los textos cristianos no hay noticias de este personaje hasta la Historia Roderici, crónica en romance fechada, aproximadamente, en 1180; el Carmen Campidoctoris, poema de un centenar de versos, en latín, compuesto hacia 1185-90, glosa también varias de las batallas del de Vivar; pero su historia se basa sobre todo en el largo e importante Cantar del Mío Cid, escrito hacia 1200. Todos las fuentes son, pues, posteriores en casi un siglo a la muerte del personaje (1099).

A partir de ahí, el Cid pasa a los textos de Lucas de Tuy, Jiménez de Rada y Alfonso X. Quien había sido probablemente un condottiero, un señor de la guerra capaz de servir a diversos reyes, cristianos o musulmanes, se convierte en el vasallo leal, el buen cristiano, la sublimación de las virtudes castellanas (cuando pide cuentas al rey por la muerte de su hermano habla, en cierto modo, en nombre del reino), el héroe nacional. Sobre el de Vivar seguirán apareciendo producciones literarias en los siglos XIV-XV y, finalmente, los falsos cronicones de Román de la Higuera, como veremos.

Otro personaje heroico del universo mitológico castellano, de gran importancia durante varios siglos, fue Bernardo del Carpio. Se le suponía ser hijo natural de una 
hermana de Alfonso II el Casto y del conde de Saldaña y se convirtió en un héroe legendario al que se atribuían muchas hazañas, entre ellas la derrota de Carlomagno en Roncesvalles o la liberación de Cataluña de los moros. Se le suponía enterrado en el monasterio de Santa María la Real, de Aguilar de Campóo, con su espada, "Durandarte", arrebatada a Roldán en Roncesvalles. Carlos V visitó este monasterio en 1522 y se llevó la espada, que actualmente está en la Real Armería de Madrid. Bernardo aparece en muchos romances épicos, en la crónica de Jiménez de Rada y sobre él se escribieron obras teatrales del Siglo de Oro. Especialmente importante fue el gran poema barroco Bernardo o La Victoria de Roncesvalles, de Bernardo de Valbuena, 40.000 versos en octavas reales muy cuidadas. Con el romanticismo, Fernández y González y otros volverían sobre él.

Un último personaje castellano mitificado que debe mencionarse aquí es Fernán González, que vivió en el siglo X. Fue conde de Lara (la de los Siete Infantes, otra leyenda castellana de largo recorrido que no interesa aquí por no ser de tipo identitario) y más tarde creador del condado de Castilla, futuro reino y eje político de la Península. Se le suponía enterrado en el monasterio de san Pedro de Arlanza, uno de cuyos monjes escribió en el siglo XI el Poema de Fernán González, que le convertía en "el Buen Conde", padre de la patria castellana. Pero no es tanto esta idealización posterior del personaje lo que interesa como conexión con los llamados "jueces de Castilla", Laín Calvo y Nuño Rasura, que según la leyenda gobernaron a los castellanos en el siglo IX de acuerdo con sus leyes y costumbres, frente a la "tiranía" de los monarcas asturleoneses. Ambos jueces aparecen mencionados por primera vez en crónicas de finales del XII, sus estatuas pueden verse en diversas iglesias y monumentos bajomedievales castellanos y el Poema de Fernán González hace de éste nieto de Rasura, como el del Cid lo convierte en descendiente de Laín Calvo. El mito de las "libertades originarias", que reaparecerá aquí varias veces, existió también en la Castilla medieval y emparentó con sus héroes.

\section{Cataluña: de la sangre carolingia al pactismo originario}

Las crónicas catalanas más tempranas son las Gesta Comitum Barcinonensium et Regum Aragonia, redactadas en el monasterio de Ripoll en diversas fases entre la segunda mitad del siglo XII y principios del XIV. Es característico de estos relatos prescindir de la Hispania prerromana y romana, e incluso dejar en un segundo plano la visigoda. Cataluña, como escribió Sánchez Alonso, a diferencia de Castilla, "ponía sus raíces en el comienzo de la Reconquista". La inicial "liberación" de las tierras catalanas de los musulmanes habría corrido a cargo de Carlomagno y sus descendientes. La propia dinastía de los condes de Barcelona, en vez de intentar emparentar con el linaje godo, hacía descender su sangre de la imperial de los carolingios. Hasta el siglo XIV las crónicas catalanas destacaban, con orgullo, la intervención personal de Carlomagno, con una supuesta expedición el 785 que arrebató Gerona a los musulmanes, y de su hijo Luis el Piadoso, conquistador de Barcelona y fundador del condado de ese nombre, que reservó para sí, lo que explicaba su primacía sobre el resto de los condados catalanes. Pero el acontecimiento fundacional, para las Gesta, sería la obtención de manos de Carlos el Calvo del dominio hereditario sobre el condado de Barcelona por parte de Guifré el Pilòs. Alrededor de la heroica muerte de este último, en lucha con los musulmanes, inventaría Pere Antonio Beuter, entrado ya el siglo XVI, la leyenda de las 
cuatro barras, dibujadas por el propio emperador francés con la sangre del Pilòs moribundo sobre su escudo de oro.

Los historiadores actuales tienden a aceptar que el Pilòs fue el fundador de la dinastía condal hereditaria, pero sitúan el paso decisivo en el surgimiento de Cataluña como unidad política emancipada de la tutela francesa a finales del siglo X, al recuperar Borrell II -sin apoyo francés- Barcelona, tras la invasión de Almanzor; lo cual, añadido a la coyuntura política que se vivía al norte de los Pirineos, con la sustitución de los Carolingios por los Capetos, le permitió dejar de rendir vasallaje a aquellos monarcas. Subrayar este hecho mostraría a la larga su utilidad para defender la tesis de la "autoliberación" catalana -y su autoentrega condicionada-, pero en la baja Edad Media se daba más importancia a la vinculación de la sangre de la dinastía condal con la imperial carolingia.

En el siglo XIII, en el que Castilla conoció sus primeras crónicas generales, la expresión más elaborada de la historiografía catalana fueron las grandes crónicas de los reinados del periodo: el Llibre dels feits del rey en Jacme; la Cronica del rey Pere e dels seus antecessors passats, centrada en Pedro III el Grande y atribuida a Bernat Desclot; la Crónica de Ramón Muntaner, uno de los participantes en la expedición de los almogávares, que narró los principales hechos políticos de la gran etapa catalanoaragonesa comprendida entre 1204 y 1327; y la Crónica de Pedro IV, un texto dirigido por el propio monarca en cuya redacción intervino Bernat Dezcoll o Descoll. De todos estos personajes regios que protagonizan las crónicas, el más destacado fue sin duda Jaume I, cuya fama fue tal que estuvo a punto de verse ungido con la santidad. Ramón Muntaner lo había llamado "sanctus rex" y Pere Miquel Carbonell y Jeroni Pau le añadirían en el siglo XV que en varias batallas se había visto a Sant Jordi combatiendo a su lado. Beuter escribió que "las maravillas que en su nacimiento y criança acontecieron [...] olían y sabían a milagros". En el siglo XVII se harían esfuerzos por canonizarlo formalmente, pero quizás menores de los que en esa misma época se hicieron en favor de su coetáneo Fernando III de Castilla, que se vieron coronados por el éxito.

A partir del siglo XIV, las crónicas catalanas tienden a prestar mayor atención al pasado peninsular común. Así ocurre con el Flos mundi, crónica universal escrita en catalán - pese al título- en la que se inserta España, y sobre todo el reino de Aragón; con la refundición latina de las Gesta Comitum Barcinonensium, impulsada por Pedro IV, a cuyo frente se incorporó el prólogo de la Historia Gothica de Jiménez de Rada. Pero fue sobre todo la Crónica de San Juan de la Peña o Crónica Pinatense, redactada hacia 1360, la que, apartándose de la habitual pauta que marginaba la España anterior a 711, comenzó por Túbal, Hércules e Ispán (a los que atribuía la fundación de ciudades catalanas como Urgel, Vich o Barcelona) y continuó por romanos y godos para llegar a la invasión árabe. Aunque mencionaba el reino de Asturias, su eje central eran los condes y reyes de Navarra y Aragón, hasta terminar con la muerte en 1336 de Alfonso IV, padre del patrocinador de la crónica. Habría que mencionar también las Memorias historiales de Cataluña, de 1418, que comienzan con los descendientes de Noé y la llegada de Túbal a Hispania, aunque tomen luego como eje los avatares del "condado catalán” hasta que Vifredo pide auxilio al rey de Francia contra los musulmanes.

La historiografía catalano-aragonesa del siglo XV dio importantes pasos para completar el ciclo legendario sobre los orígenes de Cataluña. La principal contribución corrió a cargo de Pere Tomich Cauller, autor de unas Histories e conquestes dels Reys 
de Aragó e Comtes de Barcelona (1438) que obtuvieron una copiosa difusión manuscrita y acabaron traducidas al castellano y al italiano en los siglos XVII y XVIII. Empezaban con la creación del mundo para centrarse luego en la monarquía catalanoaragonesa hasta llegar al reinado de Alfonso V; aunque no fueran su eje principal, no prescindían de Castilla, León, Portugal o Navarra, y hasta se ocupaban de Mahoma y el mundo musulmán. Pero lo importante no era eso, sino el giro que imprimieron a la búsqueda de antecedentes ilustres para Cataluña. Tomich parece haber sido el inventor de Otger Cataló, mito alternativo o complementario al de la liberación carolingia de Cataluña. Otger es dibujado como el único noble cristiano que había sobrevivido a la invasión sarracena; malherido y refugiado en los Pirineos, logró reponerse gracias a un perro fiel que le lamía diariamente las heridas y a una cabra que le alimentaba; tras recobrar la salud, convocó con su cuerno a todo el que quisiera seguirle en la lucha contra el invasor; nueve fueron los que juraron ante la "Virgen negra" luchar a su lado, Els Nou Barons de la Fama, o Cavallers de la Terra, de donde procedían las más nobles familias catalanas -al revés que el cobarde campesinado que se sometió al invasor, lo que justificaba su situación servil-; estos guerreros emprendieron el combate y a partir de ellos se realizó la división de Cataluña en "novenarios" (nueve obispados, condados, etc.). Tomich mantuvo la compatibilidad de esta historia con la de las expediciones de los monarcas carolingios. E incluso reservó un lugar para el papa en su relato, pues habría participado personalmente en la conquista de Barcelona -lo que a su vez legitimaba el pago de los diezmos-.

La obra de Tomich sería muy criticada a finales del siglo XV por Pere Miquel Carbonell, archivero de Barcelona formado en Italia. Leyendas como la de Otger Cataló sería "rises per homens letrats"; y Tomich era un historiador "moderno" (es decir, indigno de crédito), que utilizaba fuentes "apócrifas y de poca fe". Este Pere Miquel Carbonell contribuiría, sin embargo, a la creación de otras leyendas, como la aparición de Sant Jordi combatiendo al lado del rey Jaume I.

Un rasgo interesante de la historiografía aragonesa de mediados del $\mathrm{XV}$, y que preludiaba lo que ocurriría en la castellana tras la unión, fue la importación de humanistas italianos, lógica en tiempos del italianizado Alfonso V (1416-1458). Éste fue el caso de Lorenzo Valla, romano, que escribió un Historiarum Fernandini Regis Aragoniae libri tres; el de Antonio Beccadelli, el Panormita, que hizo una crónica de Alfonso V; y el de Bartolomé Fazio, que historió a Alfonso V como rey de Nápoles. Pero sobre todos ellos destacaría otro humanista, esta vez no italiano: Joan Margarit i Pau, El Gerundense (1421-1484), obispo de Gerona, canciller bajo Alfonso V y Juan II de Aragón e influyente diplomático en Roma. Según Robert Tate, fue el primer historiador hispano que, influido por los humanistas italianos, se apartó del plan de crónica peninsular trazado por el Toledano. Su título más célebre, Paralipomenon Hispaniae libri $X$, se iniciaba con una dedicatoria a los Reyes Católicos en la que hacía referencia a la unión de Castilla y Aragón en los términos clásicos de Hispania Citerior y Ulterior, remontando la pérdida de aquella unidad a la invasión árabe. Basándose en fuentes clásicas greco-romanas, describía la estancia de los griegos en la Península desde Hércules (a quien pintaba como jefe de una banda sedienta de botín, que mató a Gerión y Caco por mero interés); la de los cartagineses y las guerras púnicas, la guerra de Numancia y las guerras civiles romanas, para finalizar con la llegada de Augusto a España y la convocatoria del censo general de los súbditos del imperio. Pese a su ambición inicial, el libro de Margarit en definitiva no superó el mundo antiguo. 
Aunque recogió muchas fábulas, Margarit intentó depurar la historia primitiva y fue cuidadoso con las épocas en que podía contar con fuentes históricas fiables. En lugar de relegar el mito gótico, como tendían a hacer los catalano-aragoneses, defendió la herencia visigoda e incluso la anterior, en especial la romana. Su desprecio hacia la historiografía medieval previa era tal que reducía sus predecesores a tres "laudabiles" (Trogo Pompeyo, Orosio e Isidoro) y uno "tolerabilis" (Jiménez de Rada); el resto era, para él, un "horda ignorante, propagadores de sueños y profecías" (Tate). Como se consideraba investigador de lo "olvidado", concedía gran importancia a la etimología toponímica. Con buen criterio, diferenció a los iberos de Oriente de los de España y apuntó la procedencia gala de los celtas. Pero consideraba arios a los iberos, llegados según él de Irlanda, y establecía arbitrarios parentescos entre el idioma celta y el vascuence. Pese a su preocupación central por Cataluña, su objetivo fundamental era "proporcionar a España un renombre igual al exigido para Italia por los historiadores humanistas a través de la resurrección de la historia clásica". Como concluye Jesús Villanueva, Margarit mezcló mitología catalana y castellana y con él lanzó el goticismo en Cataluña. Sostenía que el nombre de "catalanes" procedía de "gothoalanos"; y que Barcelona había sido la primera capital goda, antes que Toledo.

\section{Los vizcaínos: héroes mágicos, tubalismo, hidalguía universal}

En la competición por justificar o anclar privilegios en la sociedad estamental, localista y corporativa del Antiguo Régimen, Juan Aranzadi o Jon Juaristi han sostenido que los vizcaínos fueron quienes lanzaron los mitos de mayor éxito, con lo acabaron asegurándose lo que todos anhelaban en la época: mayores honores y mejores derechos. Pero lo hicieron a lo largo de un proceso acumulativo y con meandros.

Los primeros relatos que avalan la antigüedad vasca son tardíos, del siglo XIV. Aparte de un par de crónicas atribuidas a fechas anteriores, pero con certeza apócrifas, el primer documento de interés es el Livro dos Linhagens, escrito hacia 1340 por el conde de Barcelos, hijo natural del rey portugués don Dinis, refugiado en la corte castellana y casado con María Díaz de Haro. En él se lanzan la leyenda de la Dama Pata-de-Cabra y la batalla de Arrigorriaga.

La primera es un ejemplo de un fenómeno interesante, aunque muy repetido: la adaptación de mitos preexistentes en otras culturas. En este caso, se trató de una adaptación de la Melusina, personaje fantástico cuya historia se narra en la novela o crónica escrita por Jean D'Arras en ese mismo siglo XIV. La Melusina, o Mère Lusigne (la mère des Lusignan) había sido una doncella de gran belleza a la que el conde Raimundo de Poitou conoció en el bosque, cuando se hallaba cazando. El conde había tenido un día aciago, porque había matado accidentalmente a su propio tío al intentar cazar un jabalí. Se acercó a la Font de Sé (Fuente de Sed) para calmarse y allí vio a Melusina, con otras hadas, danzando. Ella calmó al caballero y le sugirió cómo explicar lo ocurrido sin que fuera culpa suya. Impresionado por su inteligencia y su belleza, el conde le propuso matrimonio. Ella aceptó, prometiéndole una gran fortuna y numerosa descendencia, con la única condición de que no intentara nunca verla en sábado. Melusina, en efecto, construyó para el conde varios castillos esplendorosos y le proporcionó diez hijos; pero todos ellos tenían algún defecto físico: enormes orejas, una marca peluda en la nariz, una hendidura en el rostro, un solo ojo, un diente gigantesco... 
El conde aceptó aquellas anomalías. Pero un día, como un hermano suyo envidioso le insinuara que quizás ella no quería dejarse ver los sábados porque se encontraba con un amante, decidió espiarla: y la vio bañarse en una gran cuba de mármol, metamorfoseada en sirena, con una gran cola de serpiente. Al verse sorprendida, Melusina se arrojó por una ventana $\mathrm{y}$, desplegando unas alas de murciélago, se alejó volando. Según la leyenda, sólo reapareció, llorando desconsolada, cada vez que moría uno de sus hijos.

Para el Livro dos Linhagens, que adapta esta historia, el origen de los señores de Vizcaya venía de Diego López de Haro. Éste habría encontrado en el bosque, durante una cacería, a una mujer de gran belleza, con la que se casó, pese a tener un pie o pata de cabra, aceptando la condición por ella impuesta de no volver a santiguarse nunca. El matrimonio fue feliz y tuvieron un hijo y una hija. Años después, asustado un día el conde por un pequeño incendio doméstico, se santiguó instintivamente, con lo que rompió involuntariamente su promesa. La dama Pata-de-Cabra desapareció de inmediato, convertida en columna de humo, llevándose con ella a su hija. Con el hijo, que portaba por tanto un origen mágico, se iniciaban los señores de Vizcaya.

La batalla de Arrigorriaga, de mayor importancia futura, se remontaba a 500 años antes, en el lejano siglo IX. Munio, conde de Asturias, oprimía entonces a los vizcaínos, exigiéndoles la entrega periódica de una vaca, un buey y un caballo blanco. Pero llegó a las costas vizcaínas "un hombre bueno, llamado Froom, hermano del rey de Inglaterra, con su hijo Fortam Frooez" y se ofreció a defenderlos si lo tomaban por señor. Viendo en él un hombre de pro y alta sangre, lo aceptaron. Cuando llegó el conde asturiano con sus gentes, lucharon y los vencieron en Arguriega (Arrigorriaga). Fortam Froom casó con Elvira Bermúdez, hija de Bermudo Laínez y nieta de Laín Calvo (juez castellano, como sabemos). A él sucedió Lope Ortiz y a éste Diego López Ortiz.

La versión de García de Salazar, en las Bienandanzas y fortunas, difiere levemente: el hijo del rey de León, opresor de los castellanos, recorría Vizcaya, haciendo mucho daño, y decidieron combatirle las cinco merindades; pero él se negó a pelear con quien no fuera rey o tuviera sangre real. Apareció entonces don Zurián, o Jaun Zauría, nieto del rey de Escocia, de nacimiento mágico, y bajo su mando castellanos y vizcaínos derrotaron y mataron al rey de León en Arrigorriaga ("peña bermeja" o ensangrentada). Los vizcaínos aceptaron entonces el señorío del de Castilla pero pactando privilegios (con juramento en Santa María la Antigua, de Guernica). Más tarde, Álava y Guipúzcoa también se someterían de forma pactada a Castilla.

A este origen pactista de los fueros vascos se añadiría, en los años finales de la Edad Media, el mito de la limpieza de sangre. Las expulsiones de judíos datan de 1486 en Vizcaya, y son por tanto algo más tempranas que en Castilla y Aragón, como lo son los estatutos de limpieza o pureza de sangre. Según Juaristi, fueron la respuesta a los rumores que circulaban sobre la filiación judía de los vizcaínos (bis-caín, dos veces Caín). En todo caso, fueron importantes pasos hacia la reivindicación de la ancestral condición de "cristianos viejos" y "fijosdalgo" de los vascongados, lo que apoyaría sus demandas de exenciones fiscales y la reserva de puestos relevantes frente a los descendientes de familias conversas.

La declaración legal de la hidalguía universal se consiguió en Vizcaya en 1526 y en Guipúzcoa en 1610. La justificación, a lo largo del XVI, seguía siendo predominantemente por la ascendencia goda; así lo proclamó Arce Otálora, en su 
Summa nobilitatis Hispaniae (1559). Pero, a medida que se entraba en los últimos decenios del siglo, y al calor de la polémica sobre los fueros aragoneses en torno a Antonio Pérez y Lanuza, el relato histórico se fue reforzando y matizando. En 1564, Martínez de Zaldibia (Suma de cosas cantábricas y guipuzcoanas) cambió la justificación: el lugar de desembarco de Túbal, padre ancestral de los españoles, había sido Cantabria; hermanado con otro personaje del mismo nombre mencionado en la Biblia como experto en forja, enseñó a su pueblo la metalurgia, aparte del monoteísmo y las leyes morales "naturales"; de ahí procede también su lengua, una de las 72 "originarias" de la humanidad, las surgidas del caos babélico. Sus sucesores habrían permanecido en aquellas tierras, aislados, independientes (de romanos, godos y musulmanes) y constantemente fieles a la misma lengua: "siempre apartados de herejías, con judíos, moros ni otros infieles nunca mezclados", "sola esta nación entre todas las provincias y reinos del mundo conserva sus leyes habidas en la ley de naturaleza antes que Nino, rey de Babilonia, adulterase la áurea edad y corrompiese el mundo con la idolatría".

Esteban de Garibay autor del Compendio historial (1571), ratificó esta tesis de que Cantabria había sido la morada inicial de Túbal en Hispania añadiéndole una invención nueva: la "sequía universal" que siguió al Diluvio durante muchos meses, lo que les obligó a buscar refugio en los "aires septentrionales lluviosos". En las montañas cántabras enseñó el nieto de Noé a los de su linaje la metalurgia y "la ley de la naturaleza", dándoles "orden de bien vivir". En esas tierras tuvieron también su corte su hijo Ibero y los demás reyes inventados por Annio de Viterbo, de quien hablaremos. En ellas fundó Pelayo la monarquía hispánica. Y de ellas procedía la verdadera nobleza española, toda de sangre tubalino-gótica y libre de contaminación judeoconversa. Pero, sobre todo, allí se seguía hablando la lengua de Túbal, "llamada ahora Bascongada".

En la década de 1580, a medida que se aproximaba a su clímax el caso de Antonio Pérez y Lanuza, se incrementó la actividad inventora de fuentes medievales. De esos años procede la Crónica de Ibargüen Cachopin, "centón inagotable de fábulas y patrañas", según Andrés Mañaricúa; según ésta, quien había dictado los fueros vascos había sido Noé en persona, en una ocasión en que llegó a las montañas cántabras a visitar a su nieto. De aquel momento es también la obra Antigüedades de Vizcaya, del clérigo Martín de Coscojales, que proporcionó otro detalle que pasaría a integrarse en la leyenda: la fusión de las guerras de los cántabros contra los romanos con la idea de permanente independencia y aislamiento de los vascoiberos; con esa fiera resistencia se asociaría la permanencia del vascuence. Como prueba de la propagación de las ideas de estos historiadores, Juan de Aranzadi reproduce unas quintillas atribuidas a fray Miguel de Alonsotegui, también alrededor de 1580:

"Aquella lengua primera, / traída en la confusión, / es ahora la postrera que ha quedado siempre entera / en Vizcaya sin infición.

Es la lengua Bascongada, / según que claro lo vemos, / ni por guerra trastocada, antes aquí conservada / en tantos siglos tenemos".

Todo ello acabaría llevando a la obra de Andrés Poza De la antigua lengua, poblaciones y comarcas de las Españas, de 1587, estudiada por Juaristi, en la que los "vizcaínos" se apropiaban ya totalmente del patrimonio cultural cántabro. En esa obra y su De Hispaniorum nobilitate exemptione (1588), Poza defendía la universalidad y superioridad de la nobleza "originaria", o condición hidalga vasca, por ser "convicción 
general" que los vizcaínos descendían del patriarca Túbal y porque en Vizcaya jamás hubo "encomiendas, feudos ni vasallajes, antes todos sus hijos pertenecieron siempre a la innata libertad de las edades de oro"; además de ello, la lengua vasca era una de las "originarias" de la humanidad, infundida directamente por Dios en los primeros seguidores de Túbal, semejante e incluso superior al hebreo para expresar los misterios filosóficos y teológicos. Los argumentos de Poza serían utilizados en 1593 por Juan Gutiérrez, canónigo de Ciudad Rodrigo, en su Fueros vascos. Fundamentos de Derecho, donde defendía los privilegios forales, en especial los fiscales, apoyándose en la procedencia tubálica de los pueblos cántabros y el pacto concertado tras la batalla de Arrigorriaga. Las tesis de Poza, que contradecían directamente las del fiscal de la Chancillería de Valladolid, Juan García, triunfaron ante el monarca, que ordenó se suprimieran de la obra de García las frases impugnadas por Poza.

En favor de la excepcionalidad cántabra o vasca siguieron escribiendo en el XVII Baltasar de Echave (Discursos de la Antigüedad de la Lengua Cántabra Bascongada, 1607; la primera lengua que se habló en España) y Lope Martínez de Isasti (compendio Historial de Guipúzcoa, 1618), entre otros. Estos dos autores añadirían un dato más al mitologema, fundiendo las referencias a una supuesta batalla de Beotíbar, donde 60.000 navarros y franceses habrían sido derrotados por 800 los guipuzcoanos, con la leyenda de Roncesvalles. El primero insistió que en esta batalla sólo combatieron "cántabros bascongados" (que utilizaban "la primera lengua que se habló en España"), y no castellanos. También apoyaría la excepcionalidad vasca, como veremos, Lupián Zapata, uno de los más insignes falsificadores de la época.

En resumen, antes de comenzar el siglo ilustrado la leyenda estaba completa. No hacía falta remontarse ya a la batalla de Arrigorriaga ni a la dama Pata-de-Cabra. La limpieza de sangre, la fidelidad al cristianismo, la invencibilidad, el arraigo inmemorial en una misma casa solar, la pervivencia de la lengua originaria e incluso la mitificación de los fueros como ley divino-natural avalaban las exenciones asociadas a la "hidalguía universal". Una tesis que acabó siendo aceptada en la época sin provocar una respuesta especialmente agria.

El "cantabrismo", como escribe Fernández Albaladejo, se convirtió así en la base del "fundamentalismo español"; las montañas cántabras habían sido "la semilla viva de España", el meollo del linaje patrio. Un cantabrismo que, en todos ellos pero en especial en Garibay, estaba en las antípodas de cualquier embrión identitario de signo antiespañol. Por el contrario, y como vio Caro Baroja, el recurso a la historia era típico de aquel sector de burócratas vascongados que sirvieron a Felipe II y sustituyeron a los dirigentes banderizos del siglo anterior.

\section{La entrada en el escenario europeo y la necesidad de presentar un linaje en latín}

Que con los Reyes Católicos se abre una nueva época es un tópico mil veces repetido, pero difícil de refutar. Guicciardini, en 1512, observó que la unión de Castilla y Aragón, el fin del dominio musulmán sobre la Península, la conquista del reino de Nápoles y el descubrimiento de esos territorios oceánicos de los que llegaban metales preciosos, eran acontecimientos que "en nuestros tiempos, han centrado en cierto modo la luz en España, la han sacado de su oscuridad natural". No hay duda de que se alteraba 
el orden europeo de los últimos siglos, vivido por sus contemporáneos, especialmente desde Italia, que era uno de sus centros, como "natural".

También en los reinos peninsulares se detecta asombro ante cambios tan espectaculares. Entre los cronistas domina, en primera instancia, un entusiasmo generalizado ante lo que Andrés Bernáldez llamó la "reintegratio Hispaniae". "Hispania tota sibi restituta est", sentencia Nebrija. Fray Íñigo de Mendoza se dirige a Fernando el Católico como "tú, que en tus santas alturas, / soldaste las quebraduras / de nuestros reinos de España", y le declara, por tanto, "el que de Dios es ungido / para mandar las Españas". Es más que una "unión": es una "soldadura" o reparación de algo que estaba "quebrado", que vivía una rotura antinatural. En palabras de Nebrija, "los miembros e pedazos de España, que estavan por muchas partes derramados, se redujeron e ajuntaron en un cuerpo e unidad de Reino, la forma e travazón del cual assí está ordenada que muchos siglos, injuria e tiempos no lo podrán romper ni desatar". Así lo describen también los cronistas aragoneses, como hemos visto en la referencia de Margarit a la fusión que los Reyes Católicos habían logrado de la Hispania Citerior y Ulterior.

Estos hechos tan extraordinarios y logrados en tan breve plazo de tiempo inundaron las crónicas de componentes providencialistas, que derivaban fácilmente en el mesianismo y el profetismo. Para cualquier historiador del momento, Dios era el agente de la historia y todo acontecimiento llevaba su autoría; sólo un Maquiavelo se atrevía a atribuir los acontecimientos a la fortuna, en el sentido de azar o casualidad, o a la virtù, en el de habilidad política; para el resto, todo era producto de la voluntad divina, aunque sus razones fueran con frecuencia ocultas o secretas. Como explica al rey Fernando el doctor Palacios Rubios, hablando de la conquista de Navarra: "por razones [...] sólo a Él reservadas, ha decretado Dios quitar su reino a los reyes de Navarra y otorgarlo a Vuestra Majestad. Porque es Dios quien, en castigo de las iniquidades, transfiere los reinos de gente en gente, como dice la Sagrada Escritura".

El providencialismo llevaba al profetismo. Si lo ocurrido hasta hoy ha sido producto de la voluntad divina, es fácil deducir en qué dirección avanzará el futuro. Tanto en la Anacephaleosis de Alonso de Cartagena como en la Compendiosa Historia de Sánchez de Arévalo se parte de la evidente protección divina sobre la monarquía castellana para deducir que está destinada a llevar a cabo una grandiosa misión, aún inconclusa. Se ve en el horizonte, ante todo, la unión completa de España -la Península- con la absorción de Portugal. Eso quiere decir el aragonés Fabricio de Vagad, cuando le escribe al rey Fernando que le estaban "esperando los reynos de España", o el bachiller Palma cuando augura que con el heredero de Isabel y Fernando "todos los reynos d'España en un reyno veverán". Diego de Valera le dice igualmente a Fernando que "es profetizado de muchos siglos acá que no solamente seréis señor de estos reynos de Castilla y de Aragón, que por todo derecho vos pertenecen, mas avréis la monarchia de todas las Españas e reformareys la silla imperial de la ynclita sangre de los godos donde venís".

Al haberse manifestado el favor divino de manera tan obvia sobre las cabezas de Fernando e Isabel era indudable que se estaba entrando en una nueva era en la historia del mundo. Había surgido un nuevo imperio, comparable al persa o al romano. Tanto Margarit como Nebrija o Marineo Sículo ven las actividades de los Reyes Católicos en el contexto de la historia imperial romana. Para los más entusiastas, había llegado la monarquía universal, la culminación de la historia, con una previsible 
conquista de Jerusalén que preludiaría la entrega de la corona terrenal a un Cristo esplendoroso que descendería sobre el Monte de los Olivos. Los imperios, observaron estos profetas con una lógica aparentemente impecable, se movían de Levante a Poniente, de acuerdo con el curso del sol: nacidos en Asiria y Persia, y encarnados sucesivamente en Grecia y Roma, culminaban ahora en España, un Finis Terrae que sería también el Finis Historiae. Pedro de Cartagena le explicaba a la reina Isabel que, de las letras de su nombre, "la I denota Imperio, / la S señorear / toda la tierra y la mar". Y, al llegar a la R de Regina, disparaba la profecía hasta la culminación de los tiempos:

"Dios querrá, sin que se yerre, / que rematéis vos la $\mathrm{R}$ en el nombre de Granada. / No estaréis contenta bien hasta que en Jerusalén / pinten las armas reales".

Más discutible es que estos cantos proféticos dirigidos a los monarcas $-\mathrm{O}$ a su dinastía- fueran necesariamente el preludio de una visión nacional, en el sentido de exaltación de un grupo humano, nación o pueblo elegido, predestinado a protagonizar las empresas divinas y, por tanto, superior a los otros. Así se enseñó mucho después, en los textos históricos de orientación nacionalista (los Reyes Católicos planearon y consiguieron la unidad nacional). No era ésa, sin embargo, la orientación de los cronistas de la época, que seguían pensando en una dinastía o linaje que ampliaba sus dominios para convertirse en un imperio, mundial si era posible, no en una estructura política limitada a una "nación". El escudo de los Reyes Católicos, tan reproducido y con frecuencia llamado "escudo nacional", es una prueba plástica innegable de lo contrario a la nación: en lugar de ser simple, reducido a una figura o color o a una combinación sencilla de ambos, expresando así la homogeneidad ideal de la nación, es una abigarrada y creciente acumulación de figuras y símbolos, como corresponde a un gran poder feudal que acapara tantos reinos y señoríos como le es posible.

Pero no hay duda de que se ven forzados a derivar en esa dirección porque, al llegar a Italia las tropas del Gran Capitán, a quien se insulta es a "los españoles". Y que la polémica entre los humanistas versa sobre la antigüedad de la monarquía española o de los españoles como pueblo. Es decir, que se oscila entre la mera glorificación del monarca o de su dinastía, que es la tendencia inicial de los textos, y el ensalzamiento de una identidad colectiva, "los españoles", base del nacionalismo futuro. A esto último es a lo que obliga la salida al escenario exterior. Porque desde el extranjero no se perciben las complejidades políticas y culturales de la Península. Ya desde los concilios medievales se habían acostumbrado a considerar a los "hispani", que incluía por supuesto a los portugueses, como una de las cinco "nationes" de la Cristiandad. Ahora, con las radicales transformaciones llevadas a cabo por Fernando e Isabel, parecía confirmarse aquella unidad y se veía con más claridad que aquel territorio, Hispania o España, estaba unido políticamente, o destinado a estarlo pronto, y no se llamaba a Fernando rey de Aragón, Castilla, Navarra, Granada, etc., sino que se hablaba con naturalidad del Rex Hispaniae o Hispaniarum Rex, como le llamó el papa -por muy valenciano que fuera- Alejandro VI.

Una consecuencia de la nueva situación, y del inevitable giro de la legitimidad política, fue la transformación del relato histórico, que consistió fundamentalmente en la búsqueda de antecedentes pre-romanos, e incluso pre-griegos. Ya Pablo de Santa María, el notable judeoconverso del siglo XV, que pasó de ser gran rabino de Toledo a obispo de la misma ciudad y creó una importante escuela historiográfica, había sostenido que el 
primer rey de España no había sido Hércules, ni su sobrino o protegido Hispano, impuestos por un extranjero, sino Gerión, el héroe ibericus, el oponente de Hércules. También el catalán Margarit o el aragonés Fabricio de Vagad le negaban a Hércules la calidad de "español". La importancia del mito greco-romano iba disminuyendo, y mucho más lo haría a partir del momento en que las tropas de Fernando desembarcaron en Italia, así como disminuyó la del gótico, prescindible desde el momento en que los musulmanes habían sido expulsados de Granada. Los historiadores italianos, por su parte, retomaron la idea clásica de la incivilidad del furor teutonicus, y recibieron a esas tropas que les estaban derrotando hablando de la barbarie hispanica. Y los españoles (o combatientes al servicio de la corona castellano-aragonesa) se vieron obligados a plantear la rivalidad con los romanos como se hacía en aquella época: buscándose una antigüedad propia, superior a la del oponente.

Para este objetivo hacían falta estrategias, en principio, contradictorias. La primera, que las crónicas de España se hicieran en latín. Su finalidad era defender la importancia de la cultura "española", pero, para ganar dignidad y, sobre todo, para lograr impacto entre el público europeo, había que recurrir a la lengua internacional. Antonio de Nebrija o Lebrija (c. 1444-1522), que ha pasado a la historia como el autor de la primera gramática de la lengua castellana, se consideraba sin embargo el "primero en abrir tienda en lengua latina". Es una tendencia que se mantendría viva durante un siglo, hasta Mariana, que escribió su historia de España en latín, y que apoya la idea de que lo que primaba no era la afirmación de una cultura nacional (imponiendo la lengua castellana), sino la exaltación de una monarquía imperial.

Pero no bastó con escribir en latín. Hubo que contratar a humanistas italianos, algo nada difícil una vez que las tropas de Fernando se asentaron en Sicilia y Nápoles. Los más célebres fueron Pietro Martire d'Anghiera (1447-1526), lombardo que pasó en España los últimos treinta años de su vida bajo el nombre de Pedro Mártir de Anglería, con cargos de muy alto nivel al servicio de Isabel la Católica, como capellán de la reina y cronista de Castilla. Capellán de Fernando y cronista real de Aragón fue otro italiano, Lucio Marineo Sículo (1460-1533), que también acabó residiendo durante la mayor parte de su vida en Salamanca, donde fue ayudante de Nebrija y le sucedió en la cátedra. Marineo fue, como observa George Cirot, "el primer extranjero que publicó una historia de España". Su Opus de rebus Hispaniae memorabilibus (1530) compila diferentes textos suyos, entre los que se incluye una descripción de España que procede de su De laudibus Hispaniae (1504), un relato legendario de la España primitiva basado en el de Annio y una historia de los diversos reinos (Castilla, Portugal y Aragón, en especial este último). Fue una obra de gran éxito, traducida muy pronto al castellano. Trataba en ella también de los Reyes Católicos hasta la toma de Granada e incluía una reseña "de imperatoribus quos Hispania Romae et Constantinopoli dedit" y otra sobre "españoles ilustres", en la que procuraba fijar las raíces romanas de las grandes familias españolas. Publicó también un De Genealogia, traducido como Crónica de Aragón, donde reivindicaba la importancia de la historia aragonesa, indebidamente desatendida pese a que los reyes aragoneses también descendían de los godos y habían contribuido como todos los peninsulares a la misión providencial de expulsar a los musulmanes del país. Razón tenía Marineo Sículo en esta queja, pues es cierto que durante el reinado de Fernando e Isabel aumentó el castellanismo y la historia de los demás reinos tendió a eclipsarse. 
El más imaginativo, e interesante para nuestro tema, de los italianos al servicio de la monarquía católica, fue Giovanni Nanni, o Annio de Viterbo (1432-1502), dominico de la corte romana de Alejandro Borgia y agregado al embajador castellano en Roma, conocido por una obra impresa en Roma en 1498 titulada Commentaria super opera diversor, a veces editada como De Comentariis Antiquitatum, que no por azar estaba dedicada a los Reyes Católicos. En ella incluía una antología de textos, según él de auctores vetustissimi, pero en realidad escritos por él mismo. Uno de los objetivos, quién sabe si el principal, de este "pícaro fraile", como le llamó Bartolomé J. Gallardo, era probar que Viterbo, su ciudad natal, tenía una antigüedad muy superior a la de Roma por haber sido capital de los etruscos; para ello había hecho esculpir una losa y la había enterrado en una viña que sabía próxima a ser cavada. En sus Comentarios reprodujo ahora este supuesto hallazgo, pero se atrevió a algo más, para halagar sin duda al papa valenciano al que servía y a los Reyes Católicos. En su libro XII incluía una reseña de la España primitiva ("De primis temporibus \& quatuor ac viginti regibus Hispaniae \& eius antiquitate") en la que, apoyándose en textos -inventados- de un sacerdote caldeo -auténtico- del siglo III a. C. llamado Beroso, enumeraba los reyes babilónicos, asirios y también los "reyes antiguos de España". Esta última era una serie de reyes fabulosos iniciada, como venía siendo habitual desde Josefo y san Jerónimo, por Túbal, hijo de Jafet, que introdujo en España las letras, la música y la filosofía moral; la novedad era que, tras Túbal, la lista se alargaba hasta 24 nombres, producto casi todos de la imaginación de Annio y anteriores en 600 años a la fundación de Troya: Iberus, Iubelda, Brygus, Tagus, Betus, Gerion, Hispalus, Hispanus, Hesperus, Habis... De repente, Annio de Viterbo abría perspectivas de inesperada antigüedad a una monarquía que era "española" porque había dominado la totalidad de la Península Ibérica.

Las falsificaciones de Annio no fueron conocidas, según George Cirot, por Michel Riccio, que publicó muy poco después un breve De regibus Hispaniae libri III, en el que incluía a Gárgoris, Habis y Gerion, aun advirtiendo que no creería en ellos de no ser por la autoridad de Trogo Pompeyo. Hubo compañeros de orden de Annio, como Rafaello Volterrano y en España más tarde Melchor Cano, y otros ajenos a la orden de predicadores, como Luis Vives o Francisco Suárez, que expresaron su escepticismo ante aquellos textos y, al finalizar el siglo XVI las invenciones de Annio serían demolidas sin piedad por Scalígero. Pero en la monarquía de Fernando e Isabel resultaron muy útiles, porque probaban la mayor antigüedad de los españoles que la de los romanos. En ese sentido las aceptaron y utilizaron figuras de primera categoría, como Antonio de Nebrija, que escribió en latín una crónica del reinado, a partir de la de Hernando del Pulgar. Nebrija, cronista oficial de los Reyes Católicos, estaba preocupado por la etimología de los nombres y dedicó también a Fernando e Isabel una Muestra de la Historia de las Antigüedades en España, en la que se remontaba a los tiempos más primitivos, apostando, como ha escrito Fernández Albaladejo, por un indigenismo hispano, frente al "imperialismo cultural e historiográfico romano". Subrayaba lo sorprendente de que "una nación tan bien dotada haya padecido tantas dominaciones", aunque, al fin, se hubiera convertido en un imperio dominador. No es de extrañar que se dejara seducir por las fabricaciones del de Viterbo. 


\section{Anticuarismo y erudición en la era barroca. El frenesí falsario}

El siglo XVII, una vez muerto Juan de Mariana, fue pobre en cuanto a historias generales. Pero eso no significa, en absoluto, que el ambiente cultural descuidara o desdeñara la escritura de la historia. La propia reacción ante la obra de Mariana, muy crítica por parte sobre todo de secretarios al servicio de casas nobiliarias que no veían suficientemente reconocidos en ella sus méritos, demostró lo vivos que estaban los recelos y obsesiones sobre los tiempos antiguos. Lo estaban, pero no por las razones adecuadas; es decir, se hablaba sin parar de historia, pero no porque hubiera verdadero interés por conocer lo ocurrido en el pasado. El objetivo de tantas páginas sobre unos tiempos pretéritos reales o inventados era dotar de antigüedad a los derechos y privilegios familiares o corporativos, anclando en ella su legitimidad jurídica y ganando así primacía sobre el vecino. Como explicó Luis Vives, los autores no adoptaban la actitud del científico que intenta entender una parcela del mundo hasta entonces desconocida, sino la del político o abogado de parte que acumula argumentos favorables a una tesis decidida de antemano. Pero pocos siguieron sus consejos. Y la tendencia a exagerar o falsear los datos y aceptar leyendas, especialmente sobre las épocas más remotas, no hizo sino aumentar en el mundo ibérico en los doscientos años siguientes a la vida del gran humanista. Lo que nadie puede negar, sin embargo, es que se trataba de obras de estilo muy sofisticado: alardes de ingenio carentes de anclaje documental serio pero de espléndida composición literaria.

La floración más espectacular de falsificaciones cronísticas se produjo en el terreno de la historia eclesiástica. Desde la Edad Media se venía desarrollando una rivalidad entre Toledo y Santiago sobre la primacía entre las diócesis españolas, a la que también aspiraban Sevilla - por haber sido la corte goda en tiempos de Amalarico-, Tarragona -donde se suponía que había desembarcado Santiago- y Zaragoza -por el Pilar-. Como el llamado "voto de Santiago", prestación en especie que gravaba toda la agricultura peninsular, suponía inmensas rentas para el arzobispado gallego, eran muchos, especialmente toledanos, los interesados en negar la venida del apóstol a España. García de Loaysa, cardenal de Toledo y ayo del futuro Felipe III, publicó en los años 1580 una Colección de Concilios en la que incluyó un documento de Jiménez de Rada -obispo de Toledo también en su momento- en el que argumentaba contra la estancia de Santiago el Mayor en España. Tras leer este texto, los cardenales Roberto Belarmino y César Baronio influyeron sobre el papa para que eliminara del Breviario la referencia a la predicación de este apóstol en la Península. El escándalo subsiguiente hizo intervenir al propio Felipe II, que ordenó a su embajador Sessa defender el caso ante el pontífice. Pero, entre tanto, en España, los consternados partidarios del apóstol optaron por inventarse pruebas.

Toledo era una ciudad propicia a los falsos descubrimientos. En 1588, cuando se derribaba la vieja torre Turpiana para edificar la nueva catedral del Diego de Siloé, se descubrió una caja de plomo con reliquias y un pergamino que contenía una supuesta profecía de San Juan Evangelista en la cual se anunciaba la venida de Mahoma en el siglo VII y la de Lutero en el XVI, tras lo cual vendría el Anticristo y el juicio final. El texto era una burda falsificación, pero suscitó entusiasmo popular y fiebre apocalíptica. 
Animado sin duda por este éxito, Jerónimo Román de la Higuera (c. 15501611), jesuita toledano que estaba escribiendo una historia eclesiástica de España, dijo haber descubierto poco más tarde tres crónicas, de los siglos V, VII y X, que hizo circular manuscritas y finalmente dio a la imprenta. Atribuía la primera de ellas a un personaje real, un cristiano llamado Dextro, o Flavio Marco Déxtero, hijo de San Paciano, obispo de Barcelona, y autor de un Chronicon Omnimodae Historiae; en el documento compuesto por Higuera se encontraba la relación completa de todos los reyes de España, junto con datos sobre el cristianismo primitivo en la Península. La segunda se suponía obra de Marco Máximo, personaje igualmente real, obispo de Zaragoza en tiempos de los godos a quien se refiere san Isidoro; el texto de Higuera le hacía narrar la venida de Santiago y la conversión al catolicismo de Leovigildo, duro defensor del arrianismo. El firmante de la tercera crónica era un inventado sacerdote del siglo X, Eutrando, Luitprando o Elipando, toledano que llegó a obispo de Cremona, y proporcionaba múltiples datos sobre Mahoma, Vitiza, don Rodrigo, Carlomagno, Roldán y diversos santos y pontífices; el texto contenía una ampliación a cargo de un supuesto mozárabe del siglo siguiente, Julián Pérez, que habría conocido al Cid y acompañado a Alfonso VII en la conquista de Almería.

Varios expertos a quienes Román de la Higuera se atrevió a someter estas crónicas dictaminaron que eran falsas. Pero el jesuita, no contento con este fraude, anunció más tarde haber descubierto otro códice, atribuido a un tal Alon, o Aulus Halo, poeta de tiempos de Alfonso VI, y una carta en latín que decía haber hallado en un vaso de cobre, en una excavación, en la que se hacía referencia a un san Tirso toledano; la presión popular quiso hacer a este último santo patrón de la ciudad.

El más sensacional de estos "descubrimientos" se produjo en esa misma década última del XVI en Granada, ciudad que, hay que recordarlo, era por entonces escenario del conflicto morisco y con un cabildo especialmente necesitado de legitimidad. Al excavar en el Sacromonte para construir unos cimientos, se encontraron varias planchas de plomo enrolladas, entre huesos y cenizas, con inscripciones en árabe y latín. Versaban sobre los orígenes de la iglesia granadina, bajo Nerón, y contenían datos sobre la vida de Cristo, sobre Santiago y un discípulo suyo llamado Tesifón, martirizado en Granada -cuyos restos eran precisamente aquéllos huesos y cenizas-, además de pruebas a favor de la doctrina de la Inmaculada Concepción, otro caballo de batalla del catolicismo español. Los Plomos del Sacromonte, como fueron llamados, suscitaron de inmediato enorme entusiasmo popular. Muchos declararon haber visto luces y espíritus en la zona. El arzobispo de Granada, Pedro Vaca de Castro y Quiñones, se encontró en una posición difícil, pues simpatizaba con las presiones locales a favor del mártir cristiano que podía convertir en patrono de la ciudad, pero la opinión de los orientalistas más reputados negaba autenticidad a los plomos. Los hallazgos fueron llevados a Madrid y finalmente a Roma, donde, tras ser sometidos a nuevos análisis e informes, se acabó dictaminando, cuarenta años más tarde, que eran "puras ficciones humanas". Pero entre tanto tres reyes españoles sucesivos, Felipe II, Felipe III y Felipe IV, se habían comprometido bajo juramento solemne en favor de la autenticidad de aquellos "monumentos históricos".

El ciclo de cronicones apócrifos volvió a abrirse a mediados del siglo XVII, esta vez a cargo del clérigo ibicenco Antonio de Nobis, alias de Antonio de Lupián Zapata. Entre otras fabricaciones, éste presentó un Cronicón de Hauberto, otro de Walabonso Merio y un Martirologio de Gregorio Bético. En el primero de ellos, 
Hauberto o Huberto, supuesto benedictino de Saint Denis llegado a España con Carlomagno, explicaba la creación del mundo, las visitas a España por parte de Noé, Osiris, Hércules u Homero, la descendencia de los reyes españoles directamente de Adán y Eva y el surgimiento de distintas órdenes e iglesias españolas, con especial predilección por los benedictinos y defendiendo la primacía de Tarragona sobre todas las demás diócesis peninsulares. En el segundo, Walabonsio Merio, otro monje del siglo X, acreditaba la historia de los Siete Infantes de Lara y la aparición de san Millán en la batalla de Santisteban de Gormaz. Otra contribución de Lupián Zapata al género falsario fue una Crónica de Vizcaya, que situó a comienzos del siglo XV y atribuyó al humanista flamenco Vaseo, en la que daba fe de la existencia de un pacto de autoentrega condicionada al rey de Castilla.

Este tipo de prácticas estaban tan aceptadas en la época que incluso otros historiadores más serios (grandes bibliófilos, como mínimo) siguieron este camino. A esta categoría corresponderían las contribuciones al género de Tamayo Salazar, con un Martirologio Hispano, en el que aportaba múltiples datos sobre santos de diversas diócesis españolas. La de Joan Gaspar Roig i Jalpí, con su Cronicón de Liberato, un monje de Valclara que daba fe del desembarco de Santiago en Tarragona y la primacía episcopal de esta ciudad. O la de José de Pellicer y Ossau, autor de un Cronicón de Don Servando, obispo de Orense, supuesto confesor de don Rodrigo y, más tarde, de don Pelayo; y otro cronicón que atribuyó a Pedro Cesaraugustano, en el que narraba los 2777 años del mundo antes de Cristo, con nombres de reyes y reinas de los distintos países detallados año a año. En medio de anacronismos y contradicciones, estos escritos aportaban revelaciones sensacionales sobre la historia primitiva, especialmente eclesiástica, de España, con nuevos santos para iglesias desprovistas de ellos y ficciones que halagaban el patriotismo, la credulidad popular y las glorias locales, por lo que fueron acogidos con entusiasmo por el público y muchos historiadores. La denuncia de estos falsos cronicones sería el gran caballo de batalla de los novatores de finales del XVII y comienzos del XVIII. En el siglo XIX sufrirían la revisión crítica, muy detallada, de José Godoy y Alcántara; y en el XX Julio Caro Baroja les dedicaría su Las falsificaciones de la historia (en relación con la de España).

\section{La reacción ilustrada contra las "historias fabulosas". Novatores e ilustrados}

Hacia 1680 se detecta un claro ambiente de reacción contra los "falsos cronicones". Fue el momento de los llamados novatores -término despectivo que les adjudicó su enemigo, el obispo de Jaén Francisco Palanco-, entre los que destacaron Nicolás Antonio, el Marqués de Mondéjar, Manuel Martí y Gregorio Mayáns. Su principal obsesión fue la conseguir contrastar la autenticidad de las fuentes, clave para ellos para escribir una historia limpia de falsedades. Como dijo Feijóo, lo principal era descartar lo legendario y "maravilloso".

En esta obsesión por la autenticidad hubo, sin embargo, terrenos que quedaron fuera de la lupa crítica. Entre ellos, obviamente, el relato bíblico: la creación del mundo en seis días, el diluvio universal, Noé (y con él Túbal, aunque no para todos). Los más moderados, como Feijóo o Enrique Flórez, decidieron también aceptar las "tradiciones piadosas", como Santiago o la Virgen del Pilar. Pero hubo algo más que se consideró intocable, y esto también por parte de todos: el planteamiento nacional. Por mucho que 
se hable de la racionalidad y el cosmopolitismo ilustrados, lo que se impone como eje de la narración histórica es un sujeto que no es ni racional ni cosmopolita: la nación. "España" es, sin la menor duda, la protagonista de la historia, y se busca sin disimulo la identificación del discípulo con ella. Al igual que la Real Academia había declarado como misión propia limpiar de fábulas la historia de "nuestra" España, Iriarte habla siempre de "ellos" y "los nuestros" al referirse a las guerras históricas. En resumen, lo que pide el "progreso" en el siglo ilustrado es la sustitución de los relatos dinásticos por los que toman como protagonista al colectivo nacional.

El relato sobre la nación no se dirige ya necesariamente a demostrar una antigüedad que entronque con el origen de los tiempos, como prueba de nobleza o de procedencia directa de la creación divina; pero tampoco renuncia a remontar la historia de su protagonista a los tiempos más remotos posibles. Los historiadores más serios dejan, pues, de mencionar a los reyes fantasiosos del de Viterbo, e incluso relegan un tanto a Túbal. España inicia su curso histórico con las colonias fenicias y griegas y más tarde con la inserción en el imperio romano. Pero su existencia como "reino" independiente comienza con los visigodos. Y nadie duda de que los estudios deban centrarse en la era goda; ni deja de considerar intocable la conexión de don Pelayo con la casa real goda; lo que incluye a sus sucesores, hasta el monarca del momento.

Por esta razón, pero también porque la consideraba un modelo de política regalista, Campomanes dirigió el foco de interés de la Real Academia de la Historia hacia la época goda. Jovellanos, en su discurso Sobre la necesidad de unir al estudio de nuestra legislación el de nuestra historia, basa la historia de la constitución española en la tradición goda, recogida en el Fuero Juzgo (al que también hará referencia Argüelles, en el Discurso Preliminar a la Constitución de 1812). Juan Pablo Forner, en su Discurso sobre el modo de escribir y mejorar la historia de España, propone explícitamente que se abandonen las polémicas sobre la rivalidad con los romanos en épocas antiguas para centrarse en el estudio de la España goda y feudal, verdadero pilar de la identidad nacional. Y la Real Academia emitió un importante dictamen sobre un punto de especial significado desde el punto de vista de la definición de la identidad española: cuáles eran los "reyes españoles", pues todas sus estatuas iban a ser colocadas en las cornisas del nuevo palacio real. Esta solución ornamental se reveló técnicamente imposible dada la incapacidad del edificio de soportar tanto peso. Pero, además de los problemas técnicos, establecer la lista de los "reyes españoles" los planteaba conceptuales también, ya que se trataba nada menos que de delimitar lo español en el espacio y el tiempo. La Academia, en prueba del nuevo espíritu crítico ante las fuentes históricas, eliminó a Túbal, Hércules o Argantonio. Pero también eliminó a los emperadores romanos nacidos en la Bética -habitualmente llamados "españoles"- y decidió que el primer monarca representado en efigie en la plaza de Oriente no fuera don Pelayo, sino Ataúlfo, el caudillo que dirigía a los godos al cruzar los Pirineos, que murió a los pocos meses. Los visigodos eran, pues, los primeros reyes "españoles".

Con los visigodos había nacido "España", la España ideal o esencializada, monárquica, católica, viril (la "virilidad" de los godos era un rasgo indiscutible, frente al "afeminamiento" romano), de guerreros invencibles y, sobre todo, unida y políticamente independiente. De todos estos rasgos, el más discutible era, desde luego, el religioso. Porque al llegar a la Península los godos eran, como otros pueblos germánicos, cristianos, pero arrianos. Y la conversión de Recaredo al catolicismo ocurrió casi dos siglos después de la "entrada" de Ataúlfo, cuando ya no quedaba 
mucho más de uno de dominio godo. Pero la cronología no importa tanto en estas versiones idealizadas.

Esta veneración por los visigodos como creadores de la identidad nacional era, debe observarse, una idea contradictoria en sí misma, al menos en dos sentidos: por un lado, porque el ilustrado arquetípico se caracterizaba por un entusiasmo por el progreso que suponía desprecio y reprobación hacia todo lo que representaba la Edad Media. Al revés de lo que harían los románticos poco más tarde, condenaba el mundo medieval desde el punto de vista político, intelectual, ético e incluso estético, porque era sinónimo de violencia, incultura y barbarie, frente al grecorromano, asociado a la idea de civilización, equilibrio y dominio de los cánones estéticos clásicos. En el caso español, sin embargo, encontramos una "esquizofrenia interpretativa", en términos de J. M. Nieto Soria, pues se condena, por un lado, el Medievo como época de barbarie y anarquía feudal, mientras que, por otro, se localiza en ese momento la configuración de la identidad nacional.

El segundo aspecto contradictorio de esta idealización de la monarquía visigoda consistía en que siempre, desde aquellas crónicas medievales que habían comenzado a dibujar una identidad "española", se había insistido en un rasgo fundamental de la misma: su obstinada resistencia frente a las sucesivas invasiones. Porque la feracidad de la tierra, su riqueza minera, el buen carácter de sus naturales, capítulo inicial de toda historia canónica, provocaban inevitablemente la envidia de los vecinos, lo cual originaba intentos de invasión. Frente a tales intentos, los españoles habían mostrado una belicosidad indomable, arraigada en su celo por defender su territorio y sus tradiciones (evocada una y otra vez con referencias a las resistencias de Numancia y Sagunto frente a cartagineses y romanos, terminadas en suicidio colectivo; que podrían considerarse versiones del conocido relato judío de Masada). Sin embargo, y he aquí la contradicción, no todas las oleadas invasoras habían sido iguales. Una de ellas, la visigoda, era excepcional ya que, de alguna forma misteriosa, se había incorporado a la esencia nacional. Los libros de historia ni siquiera utilizan el verbo "invadir" cuando se refieren a los godos; los godos entran, vienen, llegan -"pasan el Pirineo", dice Ortiz y Sanz-. Y lo hacen, además, enviados por Dios para castigar la "corrupción" de aquellos malvados romanos que siglos atrás habían invadido y oprimido a los españoles.

La historiografía ilustrada, tan reacia a las "historias fabulosas" reafirma así, sin embargo, uno de los pilares legendarios de la identidad nacional: el goticismo. Un mito de gran pervivencia. Para el nacionalismo conservador, la "conversión de España" (más que de Recaredo) al catolicismo llegaría a convertirse en el hito fundacional, el momento del "nacimiento de España" (como "nación católica"). Ramiro de Maeztu, por ejemplo, escribió que "España empieza a ser" con la conversión del 589. Lo que significaba elevar la alianza entre la monarquía goda y los obispos católicos a leyenda fundacional $\mathrm{y}$ eje vertebrador de la historia hispana. Pero un planteamiento regeneracionista y modernizador, como el de Ortega y Gasset, mantendría también, en su España invertebrada, la herencia visigoda como el dato explicativo esencial -en este caso, negativo- del problema nacional. 


\section{Los mitos colectivistas: las "libertades originarias"}

Los rebeldes protestantes de la segunda mitad del XVI habían inaugurado un nuevo género de invención histórica con objetivos estrictamente políticos: en un momento en que era difícil justificar las "novedades", su propuesta de limitar el poder regio se apoyó en la idealización de una era pretérita, medieval o incluso inmemorial, en la que los reyes habían estado sujetos a límites "constitucionales". Lo que era innovador -y por tanto ilegítimo- eran las monarquías absolutas. Así lo hicieron los hugonotes franceses, como François Hotman en su Francogallia, obra cumbre de los llamados "monarcómacos", o los presbiterianos escoceses, como George Buchanan en su De jure regni apud Scotos. Sus teorías servirían de fundamento para la primera gran revolución europea, la inglesa de mediados del siglo XVII, en la que un monarca perdió la cabeza en un cadalso (previamente lo había hecho la reina escocesa, demonizada por Buchanan). Aunque sin llegar a consecuencias tan graves, algo semejante harían en España vascos, aragoneses y catalanes, entre finales del XVI y mediados del XVII, en el momento de defender sus privilegios frente a la rapacidad del fisco real, que a lo largo del medio siglo anterior había arruinado a Castilla.

El anticuarismo corporativo de la época barroca incrementó, como puede imaginarse, el celo particularista en los antiguos reinos, una operación relativamente inocua, que incluso se pudo interpretar como una rivalidad un tanto infantil por posiciones cercanas al poder, a veces meramente honoríficas, durante la época de los Reyes Católicos y Carlos V. El talante humanista impuso ciertas dosis de racionalidad, es decir, de aceptación de las leyendas heredadas o recién inventadas como un mero ornato ante cuya ingenuidad fantasiosa un intelectual sonreía con escepticismo benévolo. Pero las tensiones desatadas entre monarcas y cortes castellanas fueron auténticas, como acabó demostrando el violento estallido de las Comunidades, tras el cual el reino más poblado y más rico de la monarquía perdió toda capacidad institucional para resistirse a la voluntad regia; el estallido comunero no tuvo tiempo para producir invenciones históricas que avalaran sus demandas. Pero el ejemplo castellano, y las crecientes exigencias de armas y hombres que tan desesperadamente necesitaba la hacienda regia para abastecer a unos ejércitos extendidos por territorios cada vez más incontrolables, fue dotando de tonos agrios y tintes dramáticos a las pugnas historiográficas alrededor de pasados más antiguos y mejor documentados. Dados los efectos devastadores que la falta de protección foral contra la avidez del fisco real estaba demostrando en el caso castellano, era comprensible que las élites de los demás reinos se aferraran, cual clavo ardiendo, a unas franquicias o libertades que se suponían seculares. La invención de antigüedades se disparó, pues, de forma paralela al celo particularista.

En esa porfía se utilizó abundantemente, entre otros, el término "nación", lo que parecería indicar que surgían sentimientos precursores de los nacionalismos del XIX y $\mathrm{XX}$, pero ello debe descartarse, si por nacionalismo entendemos conciencia de identidad colectiva de la que se derivan derechos para el autogobierno. Los protagonistas políticos de los siglos XVI a XVIII no eran pueblos ni naciones, sino las élites privilegiadas de los reinos; y lo que buscaban, al exagerar o inventar antigüedades, era, como cualquier corporación de la época, blindar sus franquicias y exenciones. Aunque también es cierto que cuando le llegara el momento a la nación de buscar su propia legitimidad, siglos más tarde, siguiera la misma estrategia de las 
corporaciones barrocas -inventarse antigüedad-, para lo que le fueron de gran utilidad los mitos históricos elaborados en la época precedente.

El espacio de máxima litigiosidad, en la Península Ibérica, fue el ocupado por las obras relacionadas con el reino de Aragón. El auge que conocieron las historias particulares, dentro de aquel anticuarismo barroco que era fuente de privilegios corporativos, se cargó allí, en los últimos decenios del XVI, de una tensión mucho más alta que en momentos anteriores. El tópico heredado, sin consecuencias prácticas inmediatas, era que en el Aragón medieval los reyes habían sido electivos y que se sometían a un pacto con el reino, ante una asamblea de sus vasallos más notables. La leyenda provenía del Liber Regum, escrito en lengua romance navarro-aragonesa hacia 1200 y llamado Cronicón Villarense en su versión castellana, importante fuente de la Historia gótica de Jiménez de Rada. Según este texto, tras derrumbarse el reino visigodo se refugiaron en las montañas de Aínsa y Sobrarbe unos cuantos ermitaños y unos trescientos caballeros que, careciendo -a diferencia de Asturias- de un príncipe godo, pusieron por escrito sus libertades o fueros y, tras hacérselos jurar, eligieron a uno de ellos -Íñigo Arista- como rey. Esto ocurrió, en principio, en el siglo VIII. Pero las primeras noticias sobre tales hechos provienen de 500 años más tarde, a comienzos del XIII y son, con toda probabilidad, inventadas. Los fueros seguían siendo locales, por entonces, y sólo en 1247, bajo Jaime I el Conquistador, se promulgó una compilación general de los fueros de Aragón -corona a la que para entonces ya estaba incorporado el territorio de Sobrarbe-, elaborada por un pariente del monarca, el obispo de Huesca Vidal de Canellas o Cañellas. En el XIV, el foralista aragonés Martín de Sagarra siguió cultivando la leyenda de las libertades aragonesas, añadiendo que, a partir de Sobrarbe, aquella monarquía era electiva y que los caballeros de ese reino sólo juraban a su monarca a condición de que éste designara a un Justicia Mayor encargado de vigilar la observancia de los fueros por parte del rey y facultado para destituir a este último en caso de que los infringiera. Aunque no se conoce ningún caso de juramento regio efectivo bajo una fórmula de este tipo, la leyenda continuó y fue desarrollada a lo largo del siglo XV, en que hubo varias compilaciones de fueros aragoneses, entre ellas la de Ximénez de Cerdán, Justicia Mayor, cuyos Fueros y Observancias de Aragón incluían el supuesto texto de Sobrarbe.

La compilación de los fueros encargada por las Cortes aragonesas en 1552 repetía el mito de los fueros de Sobrarbe, constatando que "en Aragón hubo primero leyes que Reyes". Eran unos fueros o libertades muy borrosos, cuyo mantenimiento se suponía corría a cargo del Justicia Mayor, una figura más bien simbólica, de competencias mal definidas. Pero el mito llegaba hasta el extremo de asegurar que, desde Íñigo Arista, los reyes medievales habían jurado su cargo ante unas Cortes que les hacían reconocer que "Nos, que valemos tanto como Vos, y todos juntos más que Vos, os hacemos Rey si nos gobernáis bien; si no, no". Ralph E. Giesey dedicó hace ya cuatro décadas un largo estudio al surgimiento de este mito, que el propio Mariana repetiría y en el que apoyó, por cierto, sus tesis François Hotman.

Los cronistas del XVI habían insertado el reino de Aragón sin dificultades en una historia general de España. Ejemplo de ello fue Pedro Antonio Beuter, eclesiástico y profesor de la universidad de Valencia, autor de una Crónica general de toda España (1546) que era en realidad una traducción al castellano de una previa historia suya del reino de Aragón hasta la conquista de Valencia por Jaime I. Lo fue asimismo Francisco o Francesc Tarafa, canónigo archivero de Barcelona que en 1553 publicó en Amberes 
De origine ac rebus gestis Regum Hispaniae, reeditada en versión castellana en Barcelona poco después, que era sobre todo un catálogo biográfico de los reyes españoles, desde los legendarios hasta Carlos V. Ambos hicieron coexistir las fábulas habituales para la época hispánica primitiva y las catalanas para los orígenes de los condados medievales. Más importante fue Jerónimo de Zurita y Castro, zaragozano nacido en 1512, hijo de un médico real y a quien, después de trabajar en el Santo Oficio, Felipe II nombró secretario de su Consejo y Cámara. En 1548 las Cortes de Aragón hicieron de él primer cronista oficial del reino. Como tal, escribió durante treinta años una obra capital, los Anales de la Corona de Aragón, cuyo primer volumen apareció impreso en 1562 y el último poco antes de su muerte, en 1580. Ante la imposibilidad de conocer los orígenes de una "nación" -España, se entiende-, optó por historiar sólo desde la llegada de los musulmanes hasta el final del reinado de Fernando V. Para su trabajo utilizó las viejas crónicas pero también exploró los archivos ibéricos e italianos. Fue, en conjunto, un historiador mucho más cuidadoso y digno de confianza que cualquier otro de su época. Y no redujo su historia a temas de la Corona de Aragón, sino que incluyó los de otros reinos peninsulares, en especial Navarra y, desde luego, Portugal; el suyo fue un relato sobre todo político, en el que destacan casamientos, guerras y alianzas. Pero todo dentro de una perspectiva global hispana.

De no tenerla fue, sin embargo, de lo que le acusaron. Un tal Lorenzo Padilla, arcediano de Ronda, denunció el libro al Consejo de Castilla, que encargó de su censura al cosmógrafo Alonso de Santa Cruz, y éste, dolido quizás por no haber sido nombrado cronista del reino, demolió con verdadera furia la obra de Zurita por su "parcialidad por Aragón contra Castilla". En los Anales sobraban, según el censor, muchas páginas, pues se daba importancia desmedida a algunos episodios aragoneses, como la expedición de los catalanes a Grecia, "haciendo de una pulga un elefante"; quitado todo esto, "quedaría bien pequeña su Historia". Estas críticas encontraron el apoyo de nada menos que García de Loaysa, arzobispo de Toledo, pero fueron rebatidas por un segundo censor, Juan Páez de Castro, cronista de Castilla desde 1555, y también por Ambrosio de Morales, que negó la parcialidad de Zurita al decir que daba a conocer "cosas favorables a Castilla y contrarias a Aragón que no existían en las crónicas castellanas" y que incluso cargaba las tintas "más en las faltas de los aragoneses que en las de los castellanos, por lo que algunos de aquellos le tachaban de demasiado afecto a Castilla". Para Baltasar Cuart, esta polémica expresa la tensión existente entre "una visión castellanista de la historia de España y una visión más amplia que incluyese las aportaciones de la corona de Aragón". Una tensión que existía entre los mismos historiadores castellanos, como demuestra la defensa que de Zurita hicieron Páez de Castro o Morales. No hay duda de que a Zurita le inspiraban sentimientos de aragonesismo ofendido, pero no pretendía hacer una historia de Aragón al margen de la de España, sino rectificar una visión de la "nación" global demasiado dominada por el castellanismo. Era una pugna por apropiarse del sujeto "España", no bien definido aún en aquella época.

El sucesor de Zurita como cronista de Aragón, a partir de 1581, fue Jerónimo de Blancas, con quien volvió a descender drásticamente la calidad de la crónica. Si Zurita se había encontrado incómodo al tratar de las épocas primitivas, por verse desprovisto de documentos fiables, Blancas, por el contrario, "se hallaba a placer en el terreno de la ficción", como dice Sánchez Alonso, y su creatividad literaria le llevó a completar "el artilugio de los reyes y fueros de Sobrarbe, que desde Tomich y Vagad venían forjando los aragonesistas, para que el origen de Aragón tuviese así una ilustre antigüedad 
propia, independiente de Navarra". Para ello falsificó una supuesta crónica de San Pedro de Taberna, monasterio ribagorzano, y varios textos legales de Sobrarbe en latín, con el fin de demostrar que en aquellos fueros radicaba el origen del Justicia Mayor.

En aquellas conflictivas últimas décadas del siglo XVI, incluso las fantasías de Blancas podían ser litigiosas. Aquellos fueros de Sobrarbe, que su desenvoltura le había llevado a poner por escrito y en latín, se condensaban en seis preceptos o privilegios, uno de las cuales rezaba que no era lícito al rey dictar leyes sino atendiendo al consejo de sus súbditos y otro que si llegara a ocurrir que el monarca oprimiera los fueros y libertades del reino éste era libre para ofrecerse a otro soberano. Esto lo escribía en 1588; dos años después, llegó a su clímax la tensión en torno a Antonio Pérez y en 1591 fue ejecutado Lanuza, Justicia Mayor de Aragón. En medio de aquellos hechos murió Blancas y fue sucedido por Juan Costa y Beltrán, que continuó escribiendo sus anales aragoneses en tono fuerista. Lo mismo hizo el siguiente cronista, Jerónimo Martel, y éste acabó ya siendo destituido en 1608. Tanto su obra como la de su antecesor Costa fueron destruidas solemnemente en Madrid al año siguiente. Felipe III nombró entonces a Lupercio Leonardo de Argensola, célebre poeta que había apoyado al anterior monarca durante las alteraciones aragonesas de 1590-91 y que había dictaminado contra los anales de Martel. A su muerte, en 1613, le sucedió en el cargo su hermano Bartolomé, que continuó con rigor los Anales de Aragón de Zurita pero escribió, sobre todo, unas Alteraciones populares de Zaragoza en 1591, de las que ambos hermanos habían sido testigos; aunque se declaraba en ellas no "cronista del reino sino del rey", intentaba adoptar una visión equilibrada de aquellos sucesos; y aceptaba la referencia inicial a los aragoneses como titulares de los fueros de Sobrarbe, según los cuales habían aceptado tener un rey "con ciertas condiciones y leyes" vigiladas por un magistrado que era el Justicia del reino.

Lo más interesante de la reacción catalana ante las tensiones aragonesas de 1590 fue la reelaboración del ciclo legendario medieval, con significativos matices nuevos. Sobre ello ha escrito un libro cuidadoso Jesús Villanueva, a quien seguiremos en estos párrafos. El rosellonés Francesc Comte escribió en 1586 un tratado en forma dialogada titulado Il-lustracions dels comtats del Rosselló, Cerdanya $i$ Conflent, en el que se remontaba a los tiempos de Túbal y aceptaba toda la serie mitológica inventada por Annio de Viterbo, pero se apartaba de la versión tradicional sobre Cataluña al negar toda relevancia a los Carolingios en la reconquista de las tierras dominadas por los musulmanes; tal tarea habría sido llevada a cabo, según Comte, por los catos, pueblo germánico instalado en los Campos Cataláunicos cuyo príncipe era Otger Cataló.

Dos años más tarde, Francesc Calça, titular de una cátedra en la universidad de Barcelona, retomaría esta versión en su De Catalonia, una historia en latín precedida por una dedicatoria a los diputados del principado en la que explicaba lo insoportable que era la carencia de elogios y el desconocimiento que sufría Cataluña, "quae prima Hispaniae, neque ea minima portio est”. Según Calça, el pueblo que liberó Barcelona se llamaba los catalaunos, en referencia a los "Campos" de los que procedían; y no sólo se habían enfrentado a los musulmanes sino que habían reprimido también una revuelta goda en Aisó el año 827, imponiéndose así a los antiguos "hispani"; en ello se distanciaba de Comte, para quien aquellos germanos liberadores eran "nobles godos". Como Jesús Villanueva explica, no era sólo una historia de autoliberación frente a españoles y franceses, sino además una gesta colectiva, popular, de una etnia específica de la que descendían los catalanes del momento; se desplazaba así del protagonismo a 
la dinastía condal, sustituida ahora por una institución, depositaria de la herencia de aquel pueblo originario: las Cortes, compuestas por los diputados a los que Calça dedicaba su obra. Matiz importante que distinguía el caso catalán de otros hispánicos.

La cuestión de la ascendencia goda de los catalanes continuó durante mucho tiempo envuelta en brumas y disputas. El goticismo había sido lanzado por Joan Margarit, como vimos, en el siglo XV. Pere Miquel Carbonell contribuyó a reforzarlo asegurando que Vifredo el Velloso, o "Guifrè d'Arrià" era "natural del ducat de Bavaria, en Alemanya, de casa molt generosa". Lo cual conectaba con la tradición que vinculaba la etimología del término "Cataluña" con Gotholandia o Gothoalandia (de godos y alanos). Pedro A. Beuter había llamado a Guifré el Pilòs "excelentísimo godo" y para Roig i Jalpí procedía nada menos que "del linaje real" de los godos. Pero no era eso lo que más importaba. En los años en que estaban subiendo las tensiones alrededor de los fueros aragoneses, lo más relevante en un libro de historia, desde el punto de vista político, era que subrayase la "autoliberación" colectiva de los catalanes y su libre elección de soberano a partir de ese acto liberador. Se trataba, por tanto, de aplicar a Cataluña el mito de la libertad originaria y de la sumisión posterior condicionada a un monarca, con arreglo a un pacto que seguía obligando a sus herederos.

Desde los años 1550 se hablaba de un documento firmado por Carlos el Calvo, y conservado en el archivo de la catedral de Barcelona, en el que los "godos o españoles" que vivían en la ciudad condal, "para evitar el crudelísimo yugo de la raza de los sarracenos", se sometían al emperador según su "libre y pronta voluntad". El mencionado Tarafa, canónigo y archivero de la catedral, "descubrió" este privilegio y Zurita lo mencionó en su historia. Pero cuando adquirió verdadera importancia fue a finales de los años 1580, en plena crisis aragonesa. Calça, en su De Catalonia, escribía que "Cataluña nunca ha sido conquistada por reyes extranjeros", pues los godos "se entrega[ro]n por propia voluntad a Carlomagno [...] para que los proteja y gobierne"; pero, al hacerlo, habían concertado un "pacto" del que se derivaba el poder posterior de los condes o reyes, "quienes conviene que no quieran aspirar a nada más". El mito de la libertad originaria y de la autoentrega condicionada a sus monarcas quedaba así completo.

En 1603, Francisco Diago, valenciano asentado en Barcelona, publicó una Historia de los condes de Barcelona, cuya impresión fue financiada por el propio Calça, de quien era discípulo. Diago transcribía y traducía el privilegio del 844, para él una "gloria" de los barceloneses. Según él, Wifredo el Velloso era "godo de nación"; y, si bien aceptaba la conquista de Barcelona por Carlomagno el 801, añadía que lo había hecho con el concurso de "muchos godos y españoles", que previamente, además, se habían rebelado el año 781, insurrección en la que habría muerto el obispo Vives. Era una idea muy de la época, pues la compilación foral aragonesa de 1551 también había explicado que los nativos habían reconquistado Sobrarbe "con sus propias fuerzas, sin ayuda de príncipe alguno". En la década siguiente, Joan A. García de Queralbs, en una Historia de Sant Oleguer, repetía que "Cataluña nunca ha sido conquistada".

Las tensiones resurgieron cuando llegó al poder Olivares y empezó a exigir más hombres y dinero para la Guerra de los Treinta Años, la gran catástrofe europea en la que culminaron las disputas religiosas iniciadas por la rebelión luterana y que habría de marcar también el final de la supremacía de los Habsburgo españoles. El Conde-duque defendía un proyecto centralizador de la monarquía, bien sintetizado en su conocida 
recomendación al joven Felipe IV de que dejase de ser rey de Castilla, Aragón, etc., y se convirtiera en auténtico "rey de España"; lo cual significaba someter a todos sus reinos a una legislación homogénea, similar a la castellana. Frente a esta pretensión, los diputados catalanes insistieron en recordar sus fueros y privilegios. Felipe Vinyes, jurista muy conectado con la nobleza catalana, que viajó a Madrid como enviado del Consejo del Ciento para pedir al rey que fuera a las Cortes catalanas a jurar los fueros, escribió en 1622 un Memorial en el que hacía referencia a las "leyes originarias" de Cataluña, de las que decía llevar una copia. Según Vinyes, "el Principado de Cataluña fue erigido con convención y pacto de haberse de gobernar por leyes paccionadas", porque, "después de haber ocupado los moros a España (...) los catalanes que quedaron en las montañas voluntariamente y con condiciones de quedar libres y ser gobernados conforme a sus leyes (que eran las góticas), se sujetaron al emperador Carlo Magno". Los "catalanes", según repetiría Vinyes en otro escrito de 1626, no fueron, pues, "conquistados por Carlomagno, ni por fuerza de las armas, sino elegídolo y llamádolo por su voluntad, como consta por todas las historias". En estos privilegios o primeros "pactos" carolingios, llamados ahora "leyes fundamentales" (o "constitución" catalana), se fijaban los deberes militares de "godos e hispanos" respecto de los condes francos, sus exenciones fiscales y la vigencia de sus propias normas judiciales.

El mito de la autoliberación y la autoentrega condicionada no hizo sino crecer al par que las tensiones políticas de los años 1630. En él insistieron Esteve de Corbera, Francisco de Moncada, Jeroni Pujades y otros varios. Para Corbera, Otger Cataló habría sido un gobernador del sur del reino franco que acudió en auxilio de los resistentes indígenas, a petición de éstos, y los "Nueve Barones" liberaron Cataluña y se autoentregaron a Pipino y a Carlomagno. Para Pujades, Otger y los Nueve Barones fundaron monasterios y rigieron el territorio durante un largo período, hasta que en 801 llamaron a Carlomagno, que conquistó Barcelona con ellos y otros caballeros godos; el Principado, pues, "no fue conquistado, sino admitido bajo la protección, defensa y amparo real de aquellos príncipes cristianísimos".

En 1640-41, por fin, justamente con el estallido de la revuelta armada contra la "tiranía maquiavélica" del Conde-duque, apareció el gran despliegue del mitologema catalán. Corrió a cargo de Gaspar Sala Berart, popular predicador agustino, en su Proclamació Católica, y F. Martí Viladamor, en su Noticia universal del Principado de Cataluña. Ambos coincidían en subrayar la similitud entre la situación del siglo VIII, en que los "moros" no habían logrado apoderarse de Cataluña, y la del XVII, en que tampoco iban a poder hacerlo los virreyes de los Habsburgo. A partir de la teoría escolástica del origen popular del poder, los dos insistían en que el titular de la "libertad natural", del derecho soberano, era el pueblo catalán. Sala, capellán de Pau Clarís y clérigo que pronunció el sermón fúnebre de éste en 1641, se refería a la antigüedad de los catalanes, a la pureza de su fe cristiana, a los Nueve Barones como "antiguos héroes catalanes" y a los pactos establecidos con los Carolingios; sustituía la palabra "francos", de las crónicas medievales, por "catalanes", y alteraba sin el menor reparo la fecha de los privilegios para que todo cuadrara; al final, un grupo de patriotas catalanes habría liberado Barcelona en 801 y llamado a Carlomagno para someterse a su protección bajo determinadas condiciones (entre ellas, el reconocimiento de una "hidalguía universal" que ya había reivindicado Esteve de Corbera diez años antes). En cuanto a Martí Viladamor, también unificaba las leyendas medievales alrededor de una sola fecha, en este caso el 785, en que una asamblea de "próceres y magnates" catalanes, tras llamar a Carlomagno para que les ayudara a conquistar Gerona, lo habría 
proclamado rey; él mismo afirmaba haber visto y leído los documentos probatorios de estos hechos; que los castellanos negaran unas "libertades originarias" tan bien fundamentadas como las catalanas, añadía Martí, sólo podía deberse a su "furia maligna".

En la década crucial de 1640, por tanto, las tradiciones historiográficas catalanistas podían reducirse a tres: la dinástica (centrada en la leyenda de Vifredo el Velloso), la aristocrática (Otger y los Nueve Barones) y la más étnica o popular (cuyo eje eran las instituciones representativas del Principado, como defensoras del "pacto" originario). A ellas deberían añadirse otras dos, coetáneas, aunque de origen externo. La primera, la de los publicistas al servicio del rey de Francia -que durante un breve período creyó que podría añadir Cataluña a sus territorios-, como Jacques Cassan, Louis Mesplède o Pierre Caseneuve, que insistían en el carácter irreversible de los derechos soberanos adquiridos por Francia sobre Cataluña a partir del momento en que Carlomagno y sus sucesores arrebataron aquel territorio a los musulmanes. La segunda, la españolista que acabaría triunfando, elaborada por el círculo erudito del que se había rodeado Olivares, en el que destacaba Francisco de Rioja (Aristarco o Censura de la Proclamación de los catalanes, 1641) pero figuraban también filólogos y humanistas como José Pellicer y Ossau (Idea del Principado de Cataluña, 1642), cronista de Castilla que acabaría siendo nombrado también de Aragón. Todos ellos denunciaron los documentos aportados por Salas y Martí como burdas imposturas, defendiendo en cambio la continuidad histórica de la monarquía española y su unidad a partir de los Reyes Católicos.

El final de la sublevación de 1640 y de la transitoria adhesión del Principado a Francia es bien conocido. Acaso lo sea menos el silenciamiento -durante un par de siglos- de la polémica historiográfica, a partir del momento en que concluyó aquella guerra. Aunque todavía habría de tener una expresión retardada en Feliu de la Penya, que en 1683 lanzó el canto de cisne de la tradición barroca con su Fénix de Cataluña, obra en la que partía de un goticismo racial y aceptaba la autoliberación frente a los musulmanes, aunque no se refería ya al pactismo. Significativamente, este autor, activo aún durante la Guerra de Sucesión, publicaría en 1709 unos Anales de Cataluña... desde 1788 a. $C$. hasta el presente en los que no solamente se pronunciaba en favor del archiduque Carlos de Habsburgo sino que se declaraba antiabsolutista. Pero aquella guerra ya no se vería acompañada de polémicas entre historiadores comparables a las suscitadas entre los primeros años 1620 y los últimos 1640.

Añadamos, para terminar con Aragón, que los cronistas del reino seguirían existiendo hasta comienzos del siglo XVIII, cuando el cargo desaparecería junto con los fueros.

\section{La Edad de Oro en la primera generación liberal}

Es curioso observar cómo se prolongó este mito por parte de la primera generación liberal, que se limitaría a proyectarlo sobre Castilla y sobre el conjunto de España, culpando sólo a una dinastía extranjera, los Habsburgo, de haber trastocado lo que era un destino colectivo evidente por el camino de una monarquía constitucional, 
limitada por los pactos originarios. Todo ello, desde luego, partiendo de la identidad goda, que se asumía como herencia indiscutible.

Todo partió del XVIII, como tantas otras cosas del mundo contemporáneo. Sin duda por un deseo de distanciarse de la dinastía precedente a la que en el momento ocupaba el trono, se comenzó entonces a enjuiciar de forma negativa las líneas maestras de su política y a atribuirle la decadencia de, como se decía cada vez con más frecuencia, el reino o la nación. Pero no fue sólo halago a los Borbones. Juan Francisco Masdeu -que hubiera tenido razones, como catalán y como jesuita, para no simpatizar con ellos- escribió que la era imperial de los Habsburgo había llevado a España a un "estado funesto" en el que las manufacturas y el comercio se habían desvanecido. Iriarte cambiaba el adjetivo "funesto" por el de "lastimoso", y Ortiz y Sanz prefería llamarlo "deplorable". Ninguno de ellos señalaba, sin embargo, las causas de tal desastre, aparte de la debilidad de carácter de los últimos Habsburgo. Campomanes, más político, apuntaba al postergamiento de los intereses "nacionales" en favor de los dinásticos. Y Jovellanos señalaba como error básico la falta de respeto de los Habsburgo hacia la "constitución heredada" de los españoles. Juan Pablo Forner, en su Discurso sobre el modo de escribir..., hizo radicar los errores y la decadencia del reino en las "grandes revoluciones" que la dinastía austríaca había introducido en la historia española.

Se fue aceptando así, de manera gradual, la teoría del austracismo -para ser precisos, del antiaustracismo-, que en definitiva consistía en una maniobra, típica de los nacionalismos, de proyección hacia el exterior del origen de los males propios, liberando al ente nacional de toda responsabilidad por sus infortunios pasados. Quien presentó esta teoría de manera más elaborada fue José de Cadalso, en la tercera de sus Cartas marruecas, en la que culpaba explícitamente a la casa de Austria de la decadencia nacional, enumerando sus errores: Carlos I "gastó los tesoros, talentos y sangre de los españoles por las continuas guerras que, así en Alemania como en Italia, tuvo que sostener"; Felipe II siguió el mismo rumbo que su padre pero fue "menos afortunado", porque "no pudo hallar los mismos sucesos aun a costa de ejércitos, armas y caudales", con lo que "murió dejando a su pueblo extenuado con las guerras, afeminado con el oro y la plata de América, disminuido con la población de un mundo nuevo, disgustado con tantas desgracias y deseoso de descanso". La causa de la decadencia no era, por tanto, la debilidad de carácter de los tres Austrias menores, sino el programa establecido por los dos mayores. A la muerte de Carlos II, España era, según la imagen de Cadalso, "el esqueleto de un gigante", debido a las "largas guerras, lejanas conquistas, urgencias de los primeros reyes austríacos, desidia de los últimos, división de España al principio del siglo, continua extracción de hombres para las Américas..." Felipe V, al llegar en 1700, se había encontrado con un país "sin ejército, marina, comercio, rentas ni agricultura".

Esta idea de Cadalso fue reiterada de manera mucho más mordaz por Manuel José Quintana en su composición poética de 1805, de gran impacto político, "El Panteón de El Escorial". Penetraba en ella el autor imaginariamente en aquel edificio, "padrón sobre la tierra / de la infamia del arte y de los hombres", donde, "bajo eterno silencio y mármol frío, / la muerte a nuestros príncipes esconde". Invocaba a los sepulcros $\mathrm{y}$, entre alaridos lastimeros y violentas ráfagas de aire que amenazaban con apagar su antorcha, aparecía el ánima en pena de Carlos V, que confesaba:

"Yo los desastres / de España comencé y el triste llanto 
cuando, expirando en Villalar Padilla, / morir vio en él su libertad Castilla. Tú [Felipe II] los seguiste, y con su fiel Lanuza, / cayó Aragón gimiendo..."

También desfilaban, para completar la secuencia familiar, Felipe III (con un triste "yo nací para orar"), Felipe IV ("embebecido entre festines") y Carlos II ("yo, inútil..."). Tras ellos, la conclusión era desoladora: “iOh, Dios! ¿Y esto era rey a tanto imperio?”.

Sentaban así los ilustrados los cimientos de uno de los pilares de la mitología nacionalista, al atribuir la responsabilidad de las desgracias colectivas a un elemento "extranjero", en este caso una dinastía alemana o flamenca. Les faltaban muy pocos pasos para completar el mito: uno de ellos, el elemento martirial y de expulsión del Paraíso, localizado en la ejecución de los dirigentes comuneros en 1521; otro, la llamada "convivencia de las tres culturas" o religiones monoteístas, para completar el dibujo del paraíso inicial con un ambiente de tolerancia desconocido en el resto de Europa, que haría de la España medieval una especie de Holanda o Estados Unidos avant la lettre. Todo llegaría, poco más tarde, con la primera generación liberal revolucionaria o en el curso de la guerra carlista y el agravamiento del conflicto entre Estado e Iglesia. En cuanto a los mártires, el propio Quintana ya se refería en su poema a Padilla y a Lanuza; y al primero le había dedicado, en fecha tan temprana como 1797, una "Oda a Padilla", que fue prohibida por la Inquisición y sólo pudo ser publicada durante la guerra napoleónica. En ella, el propio Padilla se presentaba como modelo para quienes luchaban por la libertad en los tiempos que corrían: "Yo dí a la tierra el admirable ejemplo / de la virtud con la opresión luchando".

Esta interpretación simplificada y maniquea del pasado nacional se hizo moneda común, especialmente en medios liberales, al calor de los debates políticos gaditanos, en plena guerra con los franceses. Todos los conflictos por los fueros de los reinos en los siglos XVI y XVII se presentaron entonces como justas rebeliones del "pueblo español" contra la tiranía de una dinastía "extranjera", e incluso se remontaron sus antecedentes a épocas tan remotas como la del rey Suintila. Pero el papel estelar correspondía sin duda a la sublevación de las ciudades castellanas contra Carlos I en 1520, interpretada ahora como una defensa de las libertades nacionales contra la tiranía, en que la heroica derrota y muerte de los "patriotas" significó el fin del poder de las cortes y el inicio de tres siglos de absolutismo en España. A esos siglos de "esclavitud de la nación" era a la que los nuevos patriotas de 1808 querían poner fin. En la línea de Quintana, Jovellanos se refirió a la causa castellana, vencida "por la intriga y la fuerza", pero no por la "razón", pues la avalaba el derecho de "supremacía" de la nación; el diputado americano Mejía Lequerica cantó al "divino Padilla, ápice sumo del saber y de la libertad y de la virtud"; Canga Argüelles, al "inmortal Padilla", "adalid de los derechos de la nación", que al lanzar su "grito de la libertad" reclamó, en nombre del pueblo soberano, sus "derechos sacrosantos"; y Martínez Marina a la "desgraciada" y "gloriosa" batalla de Villalar, sostenida por "el patriotismo y el amor a la libertad".

Puesto que la candente actualidad política, a partir del momento en que se planteó la necesidad de oponer un proyecto de reformas a las adelantadas por José I en Bayona, giró en torno a la reunión de una representación nacional, el interés de quienes se negaban a aceptar la legitimidad de Bonaparte se centró en las Cortes medievales, consideradas el bastión de las libertades colectivas frente al despotismo de los reyes. La referencia a aquella institución histórica era una forma de justificar, no sólo la convocatoria de una asamblea representativa de la "nación" en 1810, sino también los 
radicales cambios institucionales y legislativos que pensaban proponer a aquella asamblea. Se aceptó como lugar común el hecho de que un sistema de limitación y control de los poderes y defensa de las libertades ciudadanas no era ninguna novedad en España, sino que respondía a unas formas de convivencia y unas instituciones que habían existido en la historia del país en los momentos en que éste no había estado sometido a una dominación extranjera; es decir, que era justamente lo que se adecuaba al carácter y al genio nacional español. Porque hay que insistir en que aquella situación de libertad no había sido un episodio pasajero ni sepultado en la noche de los tiempos. Los españoles, en realidad, siempre que no habían visto usurpados sus derechos colectivos por una tiranía foránea se habían organizado de esa manera. La historia demostraba que eran un pueblo libre por naturaleza.

Aquel historicismo liberal puesto al servicio de un programa de reformas políticas radicales tuvo que enfrentarse, como no podía ser de otro modo, con muchas contradicciones. Una de ellas fue la geográfica. La Constitución de 1812 identificaba a la nación española con la monarquía imperial, que incluía los territorios americanos, considerados provincias del reino y poblados por españoles, iguales, en teoría, a los peninsulares. Sin embargo, al buscar antiguas tradiciones liberales, todas las pruebas acumuladas se referían al pasado peninsular. En la época medieval, por otra parte, la Península había estado constantemente dividida en reinos independientes, lo que tampoco era fácil de compatibilizar con una única tradición política. Una dificultad, esta última, que se convirtió en ventaja, ya que se consideró válido traer a colación ejemplos de cualquiera de los antiguos reinos, siempre que sirvieran a la causa liberal. Por otra parte, la fragmentación medieval se contrapesaba con el ejemplo godo, que reforzaba la idea de la milenaria unidad nacional y probaba el común origen español de todos los reinos cristianos posteriores. Es más, se daba por sentado que las leyes visigodas habían inspirado las de estos reinos, cuyas cortes, por ejemplo, eran mera prolongación de los concilios toledanos.

Los liberales, de esta manera, exaltaron por igual leyes godas, como el Fuero Juzgo, algún pacto preconstitucional legendario, como el "fuero de Sobrarbe", instituciones como las cortes o diputaciones catalanas o el Justicia Mayor aragonés, y leyes, costumbres o fábulas procedentes de Navarra, Valencia, Asturias o Vizcaya. En realidad, si se exceptúa el episodio comunero, Castilla era la región a la que menos referencia se hacía inicialmente. Un catalán como Antonio de Capmany tenía incluso mal concepto del caso castellano. Y un aragonés como Isidoro de Antillón, al anotar la Carta de Pérez Villamil que reconocía el poder histórico del rey para dictar leyes, apostillaba que "esto se entiende en Castilla", porque "jamás en Aragón se desprendieron las cortes del poder legislativo". El mismo Antillón, en su Lo que debe preceder a las cortes, no consideraba a "las antiguas cortes españolas y menos las de Castilla" una "verdadera y libre representación nacional", mientras que ensalzaba las libertades del antiguo reino de Aragón, donde el Justicia recordaba al monarca "los límites de su poder" y velaba por los "derechos del pueblo"; todo ello, naturalmente, hasta que Felipe II pisoteó los fueros y ejecutó al Justicia Lanuza.

A quien tocó defender las libertades históricas castellanas, y completar así el mito de la España medieval liberal, fue al historiador del derecho Francisco Martínez Marina, clérigo asturiano y académico de la Historia. Éste presentó, excepcionalmente, la historia constitucional castellana como la tradicional de España y trazó desde ella la evolución de la nación como sujeto soberano. Marina se había aproximado a las leyes 
fundamentales castellanas, del Fuero Juzgo a las Partidas, en su Ensayo históricocrítico sobre la antigua legislación... de los reinos de León y Castilla, texto de 1806 impreso en 1808. Presentaba allí las leyes del siglo VII como el "primer cuerpo legislativo" español, pues los godos, tras triunfar sobre los romanos y ocupar "toda" la Península, pusieron los cimientos de una monarquía "que se perpetuó felizmente" hasta el XIX. Por esa razón, dedicaba aquel Ensayo a recopilar leyes medievales útiles para un nuevo código, ensalzando el Fuero Juzgo y criticando las Partidas. Pero algo de lo que allí decía iba a ser inaceptable para los liberales del período bélico: que en la Edad Media española era el monarca, y no las cortes, quien detentaba "la facultad de hacer nuevas leyes [...] y aun renovar las antiguas". Incluso Jovellanos rechazó expresamente esta idea en su Memoria, en la que atribuía la potestad histórica de legislar no sólo al rey, sino "también a nuestras Cortes".

A partir de la ocupación francesa, el pensamiento de Martínez Marina evolucionó con rapidez y sus trabajos históricos aportaron más argumentos que los de ningún otro en favor de las propuestas liberales. Desde octubre de 1808 circuló un escrito suyo, un Discurso sobre el origen de la monarquía y sobre la naturaleza del gobierno español, en el que apoyaba la convocatoria de las cortes generales a partir de las tradiciones medievales. La obra fue publicada íntegramente en 1810 y Blanco White la reseñó en su periódico londinense, El Español, con el título de Carta sobre la antigua costumbre de convocar las Cortes de Castilla para resolver los negocios graves del Reino. Las ideas allí recogidas fueron desarrolladas por Martínez Marina en su obra capital, que empezó a escribir entonces y publicaría en 1813: la Teoría de las Cortes o grandes Juntas nacionales de los reinos de León y Castilla. Monumento de su constitución política y de la soberanía del pueblo, en la que se incluía, como prólogo, su anterior Discurso.

En cuanto a los orígenes, Martínez Marina partía del mismo presupuesto mítico que el padre Isla había enunciado en la contundente primera línea de su versificado Compendio de Historia de España ("Libre España, feliz e independiente / se abrió al cartaginés incautamente"): los españoles originarios habían sido libres, tanto respecto de toda sujeción foránea como frente a tiranos internos; porque habían rechazado a todo invasor extranjero y entre ellos habían adoptado, de forma natural, un sistema de gobierno no opresivo. Los "españoles" existían, pues, en la historia ya en época prerromana, y desde aquel lejano momento aparecían venerando "su amada libertad". La resistencia -o "santa insurrección"- frente a los romanos, que duró "doscientos años", acabó siendo aplastada por el "insidioso y falaz" invasor, debido sobre todo a la división interna de los nativos, por lo que al final España "sujetó el cuello al yugo del vencedor". Fue aquella una etapa de esclavitud, que Marina dibuja con trazos tan duros que hacen pensar en su proyección sobre la presencia de los ejércitos napoleónicos mientras él escribe. Como observó José Antonio Escudero, sorprende, como mínimo, que un eclesiástico, e historiador del derecho, no valorara ni la introducción del cristianismo ni la del derecho romano. Este largo sufrimiento cesó con los visigodos, creadores de "la monarquía española". Con ellos, "nuestros padres recobraron la independencia y la amada libertad" y establecieron "nuevas leyes, nuevas instituciones, nueva jurisprudencia, nuevas costumbres, nueva forma de gobierno, nueva Constitución". Tanta novedad, sin embargo, encubría la restauración de algo permanente, esencial, innato, perteneciente a la forma de ser y convivir del "genio español": la situación de libertad, y consiguiente felicidad, de España. 
"Por segunda vez" peligró esta situación con la invasión musulmana. Pero el orden gótico sobrevivió en Asturias, y se emprendió la lucha para restaurarlo frente al dominio sarraceno, lucha que se prolongó demasiado por la falta de unidad entre los "españoles". Hacia el siglo XII, con todo, en Castilla y León la libertad se había restablecido plenamente. Gracias, en especial, a las cortes populares, unos parlamentos que reproducían el modelo de los concilios toledanos - por lo que fueron similares en todos "los Estados monárquicos que en la Edad Media se fundaron en España"- y que frenaban "el despotismo aristocrático y sacerdotal". A las cortes se añadirían los fueros o legislaciones particulares de cada reino o localidad y las instituciones municipales de gobierno con participación popular, como los cabildos abiertos. Y se añadió la monarquía, que pasó a ser hereditaria también por entonces, cosa que se hizo con el "consentimiento del pueblo", el cual se reservó "tácita o expresamente" el poder de "hacer en estos actos como en otros asuntos lo que le pareciese más ventajoso al Estado". Aquel clima de libertad explicaba el renacimiento cultural iniciado en la Castilla del siglo XIII y culminado con los Reyes Católicos, que coronaron la secular Reconquista y pusieron las bases de la unión política, elevando así a "la monarquía española al punto de su mayor esplendor".

La mala fortuna quiso que la real pareja no tuviera herederos varones, razón por la que, en el siglo XVI, el trono pasó a manos de los Habsburgo. "Los príncipes de la nueva dinastía austríaca, acostumbrados al despotismo y gobierno arbitrario, e ignorando las leyes y costumbres de estos reinos, atropellaron lo más sagrado de nuestra constitución". Para Marina, Carlos I fue nada menos que "hombre suscitado por Dios para azote y castigo de la humanidad"; y Felipe II "tal vez excedió a su padre en orgullo y despotismo". El absolutismo se prolongó y hasta "llegó a su colmo" con los Borbones -añadido novedoso, que demostraba cómo estaban cambiando los tiempos-, con lo que se "consumó nuestra ruina"; la nación, así, "se convirtió en patrimonio del príncipe, dejó de ser nación". Esos largos trescientos años de abandono de la tradición y de ignominioso sometimiento habían terminado, por fin, con la "santa revolución" de 1808. En aquella fecha España recobró su "antigua independencia y libertad", y la nueva Constitución de 1812 garantizaba su futuro, con lo que se estaba entrando en una nueva y definitiva fase de "regeneración" de España.

La visión histórica de Martínez Marina se inscribía en una lucha o tensión permanente entre el "despotismo" y la "libertad". Tensión que, proyectada sobre el caso español, adquiría otro sentido, pues significaba la alternancia entre fases de "afirmación de la propia identidad" y de pérdida de la misma, en función de que los españoles gozasen o no de "libertad e independencia". En pleno debate constitucional de 1812, esta reinterpretación histórica, que tomaba como eje unas instituciones medievales castellanas idealizadas, aportaba un sustancial apoyo al proyecto liberal. Porque la "tradición nacional" adquiría con ella una sorprendente continuidad entre la época prerromana, la monarquía goda, los reinos medievales cristianos y el momento que se vivía de rebeldía frente a los franceses y autogobierno.

Lo que más sorprende de este planteamiento de los que se empezaban a llamar "liberales" es que anclaran la legitimidad de sus reivindicaciones en la historia, en vez de apoyarse en la argumentación racional, como habían hecho los revolucionarios franceses. Porque si algo caracterizaba al progresismo ilustrado y liberal es que no aceptaba la antiguiedad como título de legitimidad. Como explicaba, con buena lógica, Isidoro de Antillón, en su Lo que debe preceder a las Cortes (1810), lo que llevaría a 
los españoles al "templo de la libertad" era "la razón y no los ejemplos sacados de los viejos pergaminos". En una idea semejante se había apoyado alguien tan influido por la situación francesa como Francisco de Cabarrús, cuando lanzó sus radicales Cartas sobre los obstáculos que... oponen a la felicidad pública (1792, publicadas en 1808), donde, distanciándose del historicismo dominante entre quienes proponían reformas políticas, tiraba todo el pasado por la borda y exigía "regenerar la nación" y "borrar las equivocaciones de veinte siglos". Posiciones semejantes mantendrá, poco más tarde, Sempere y Guarinos en su crítica a la obra de Martínez Marina.

Pero Antillón, Cabarrús y Sempere eran la excepción (y no es casual que los dos últimos fueran "afrancesados"). La mayoría de los pensadores políticos de la última generación ilustrada y primera liberal se refugiaron, en el caso español -como en tantos otros europeos-, en el mito histórico de la nación libre. Éste resultaba muy conveniente, sin duda, en un momento de rebelión contra los Bonaparte, para evitar toda posible acusación de afrancesamiento. Pero esa búsqueda de antecedentes para respaldar el proyecto anti-absolutista venía de mucho antes de 1808 , como sabemos. Y a partir de ese año pasó a ser prácticamente unánime, compartida por todas las corrientes políticas. Jovellanos, ejemplo del reformismo moderado, utilizó esta apelación a la "restauración" de la constitución histórica con el fin de huir de los radicalismos revolucionarios e imprimir al cambio político que creía inevitable un carácter reformista y moderado. Pero los jóvenes liberales, al reivindicar el derecho de los españoles a dotarse de una constitución sin intervención del rey, optaron igualmente por demostrar el arraigo secular de la libertad en España, es decir, por "inventar la tradición”, reinterpretando los datos históricos para deducir de ellos la existencia de unas instituciones y costumbres "españolas" que coincidían grosso modo con las reformas que ellos proponían. Incluso quienes pretendían mantener el absolutismo recurrieron a la historia para defender su propuesta. Pero en ellos era más lógico.

\section{Epílogo y conclusión. Los "renacimientos" medievales en la época romántica, base de los modernos nacionalismos}

Según su plan inicial, este trabajo debería completarse con un último apartado sobre la reactivación de las leyendas medievales en las décadas centrales y finales del siglo XIX, bajo el influjo del romanticismo y del nacionalismo imperante en esa etapa. Y hasta cabría añadir unas páginas sobre su posible supervivencia en la España actual. Pero ya hemos martirizado suficientemente al lector con un texto abrumadoramente largo y plagado de nombres y datos. Digamos simplemente que, siguiendo el exitoso modelo del "Risorgimento" italiano, en la España del XIX se produjeron una serie de "Renacimientos" ("Renaixença", "Rexurdimento"), cuya orientación principal consistió en relanzar los mitos medievales. Su sabor, al principio, fue más literario que político, pero acabarían sirviendo de base para los planteamientos nacionalistas.

Esto fue especialmente evidente en el caso catalán. Desde las obras de Prosper Bofarull o Joan Cortada en los años 1830, o los volúmenes sobre Cataluña de Pau Piferrer en los Recuerdos y bellezas de España, hasta las de Víctor Balaguer o Lluis Cutchet en los 50 y las de Antoni de Bofarull o Antoni Aulestia en los años 70 y 80, hubo una idealización progresiva de la Edad Media catalana como una época heroica, gloriosa y en la que los catalanes disfrutaron de una libertad luego perdida. Un papel 
especialmente importante en la vertebración de este catalanismo sentimental, fue desempeñado por Els Jocs Florals, concursos poéticos que cultivaban, a la vez que la lengua, la idea de "patria". Aquella afirmación identitaria se entendió en esas décadas como perfectamente compatible con la adhesión a España. Fue un momento de dualidad de fidelidades, de "doble patriotismo", según el término acuñado por Josep María Fradera: la catalana, más centrada en los terrenos linguiístico, cultural e histórico; la española, referida al plano político. Pero la historia, como diría el propio Duran y Bas, desempeñó una función básica en la "recuperación" de la conciencia nacional. En los propios años 80, con la campaña contra el Código civil, lo cultural se convirtió en una reivindicación jurídico-política; y el paso a la política estricta se daría, más tarde, con las Bases de Manresa y la Lliga Regionalista. Como en tantos otros casos, literatos e historiadores vinieron primero y juristas y políticos más tarde.

No muy distinto fue el caso vasco, donde los fueros, tan desprestigiados en el XVIII (contra ellos escribió Juan Antonio Llorente; y fue contundente el Diccionario Geográfico de la RAH), estuvieron a punto de ser eliminados tanto en la Constitución de Cádiz como en la de Bayona. Pero Fernando VII los mantuvo y las leyendas históricas en las que los fueros se apoyaban reaparecerían con fuerza con el romanticismo y las guerras carlistas. Luis Viardot, en 1836, repitió que las provincias vascas habían sido independientes en la Edad Media y sólo se asociaron al reino de Castilla de forma condicionada; que no habían estado sometidas a romanos, godos ni árabes; y que desde tiempo inmemorial se celebraban Juntas vizcaínas bajo el célebre árbol de Guernica. Juan E. Delmas, el llamado "padre del periodismo vizcaíno", sostuvo en 1868 que en España nunca hubo propiamente feudalismo y Vizcaya no pudo, por tanto, ser feudo de Castilla; que los vascos siempre había sido iguales entre sí y que su territorio había sido independiente hasta que, tras la batalla de Arrigorriaga, bajo el mando de Jaun Zauría, aceptaron al rey de Castilla siempre que jurara respetar los fueros y libertades. En la última década del siglo, Sabino Arana volvería a repetir la leyenda de la independencia, la pureza de sangre y la hidalguía universal; pero esta vez ya imprimió a todo ello un giro secesionista: los vascos nunca habían sido españoles.

Podríamos aludir también los casos gallego (Martínez de Padía, Vicetto, Brañas, Murguía, Verea y Aguiar), andaluz (de Joaquín Guichot a Blas Infante), aragonés (Braulio Foz) o valenciano (Vicente Boix), pero nuestra investigación se halla todavía en sus inicios en estos temas. De ellos, el mayor interés parece corresponder al gallego, sobre el que se detecta en principio el impacto del racismo (obvio también en Sabino Arana), dominante en los ambientes europeos de la segunda mitad del XIX. El mito gallego fue el celtismo, que permitió elaborar la leyenda de los antepasados nobles que habrían vivido una Edad de Oro truncada por una intervención foránea: en este caso, la de los romanos, según Verea y Aguiar, que también narra la historia del Monte Medulio, donde los galos asediados cometieron suicidio colectivo, prefiriendo perder la vida antes que la libertad. Una versión más de Numancia o Masada.

Este sumario recorrido de ningún modo debe dejar de lado el más importante y exitoso de todos los relatos, y con el que los demás rivalizaban: el español, apoyado sobre todo en los mitos castellanos tal como habían sido formulados por la primera generación liberal (la iniciadora, en definitiva, del revival medieval del romanticismo decimonónico). En el caso castellano/español, a comienzos del XIX, con la guerra napoleónica, resurgió con fuerza el mito del pueblo que había luchado obstinadamente, a lo largo de milenios, por el mantenimiento de su identidad e independencia contra 
sucesivas oleadas de invasores. Zaragoza y Gerona, repeticiones de Numancia y Sagunto, bastaban para probarlo. Nadie se planteó nunca el desmentido de esta versión de la identidad nacional por la extremada facilidad con que el país se abrió ante la invasión musulmana (la más trascendental de las oleadas invasoras), tras una sola batalla y sin caso alguno conocido de resistencia numantina ante los sarracenos. Pero ya se sabe que los mitos, al revés que la ciencia, no se someten a falsación. También se mantuvo durante todo el siglo la presentación de la derrota comunera y las ejecuciones de Villalar como el momento de salida del Paraíso, con extraordinarias celebraciones en su tercer centenario, en pleno Trienio Liberal. Y se cultivó la leyenda de El Cid, que habría de culminar, ya entrado el XX, con la interpretación nacionalista de Menéndez Pidal. Otra actuación, más anecdótica, del XIX que corrobora este dominio del historicismo podría ser la restauración del nombre de Sagunto -en diciembre de 1868, en otro momento de revolucionario, pero también coincidiendo con la pleamar nacionalista alemana e italiana- para la ciudad valenciana que durante muchos siglos se había llamado Murviedro (Morvedre, en valenciano; Mure Vetere).

Nuestra conclusión no será larga ni compleja. Frente a la definición aristotélica del ser humano como animal racional, aceptada durante milenios, en los años 1930 Ernst Cassirer propuso entenderlo como "animal simbólico". Los humanos, según Cassirer, no podemos enfrentarnos con nuestra realidad sin crear símbolos, objetos o términos "designadores de sentido", que nos arropen y den fuerza. Todo el proceso de creación cultural -religión, artes, filosofía, ciencias- se encuentra cimentado en el pensamiento simbólico. Los símbolos nos proporcionan estabilidad, seguridad, identidad.

El simbolismo también se desenvuelve en el tiempo, presentado como secuencia de presente, pasado y futuro. La historia cumple una función esencial dentro de la creación simbólica, pues narra los orígenes, que explican y dan sentido al presente. Más aún, la creación de historias nos arrastra a mundos de añoranza, nostalgia y melancolía por lo que fue, a la vez que fundamenta esperanzas en un mundo mejor. Los relatos sobre los orígenes dan sentido a la sociedad y legitiman ciertas propuestas políticas. Al ser estas propuestas cambiantes, convierten en inevitable la evolución y reformulación de los mitos. Unos mitos que definiremos, para entendernos, como narraciones legendarias sobre los orígenes de nuestra comunidad; lo que incluye héroes o mártires que encarnan valores que se supone la vertebran.

Al igual que todo símbolo, pero con mayor potencia, la historia mitificada proporciona identidad, legitimidad y autoestima. Identidad, ante todo, porque conecta nuestro ser colectivo con otro al que el relato histórico presenta como dotado de continuidad y coherencia. Legitimidad, en segundo lugar, para las estructuras políticas actuales, que se presentan como adecuadas a, y representantes de, esa identidad colectiva que, dada su larga existencia, debe considerarse "natural" y única posible. Prestigio y autoestima, por último, cimentados en las portentosas hazañas o inigualables virtudes de esos antepasados imaginarios. De ahí la vinculación emocional con ellos y la reacción ofendida cuando se cuestionan o ridiculizan esos relatos, cosa por otra parte tan fácil de hacer, dado su carácter infantil, y que todos hacemos con los mitos del vecino, -o lo haríamos si nos molestáramos en conocerlos y pensar sobre ellos-.

En la Península Ibérica, de forma paralela a la de otros tantos casos del entorno, el relato legendario se relacionó en una primera fase con héroes fundadores y dioses o 
semidioses provenientes de la mitología greco-romana. El cristianismo añadió -a veces, simplemente sobreponiéndolos, sin sustituirlos por completo- hechos y personajes bíblicos o evangélicos. La siguiente fase, la medieval, se centró más bien (aunque, de nuevo, sin abandonar los relatos anteriores) en la prosapia de sangre -de godos o carolingios- y las grandes hazañas guerreras de los antepasados. Y el mundo moderno pasó al héroe colectivo, lo que facilitó la continuidad en el tiempo y su utilización política. Esta última fase comenzó con la legitimación protestante de las revoluciones liberales y culminó en los nacionalismos. Aplicándole al sujeto colectivo el mitologema clásico, aparecieron las referencias a una Edad de Oro perdida, en la que "nuestros antepasados" disfrutaron de unas libertades originarias o naturales cuya recuperación se planteaba ahora como imperativa. Es bien conocida la utilización política de la historia, o incluso su manipulación consciente, en el caso de los nacionalismos. Pero tampoco los monjes medievales o humanistas renacentistas que fabricaban documentos atribuidos a personajes antiguos realizaban su tarea falsaria de forma involuntaria.

En la España actual, la complacencia con los mitos heredados corresponde sobre todo a los nacionalismos periféricos. Pero no es malo que quienes no estén dispuestos a aceptar esas construcciones se prevengan contra la tentación de combatirlas defendiendo otras de signo opuesto. Si se quiere construir una Historia que tenga algún viso científico, el propósito debe ser simplemente comprender los acontecimientos pretéritos, sometiéndolos a un esquema explicativo racional. Nunca debe renunciarse a la exigencia ilustrada de ser críticos con cualquier dato no fundamentado. Pero parece, sobre todo, necesario que el historiador tenga sentido histórico, evitando proyectarse retrospectivamente e identificarse con unos personajes y situaciones que, en realidad, le son radicalmente ajenos. Sin ánimo de terminar estas páginas con una moraleja, o de convertir en normativo un texto que quiere ser analítico, quizás no sería malo recordar al sabio valenciano -más sabio que valenciano- Juan Luis Vives, que a comienzos del XVI dedicó unas breves pero luminosas páginas a la escritura de la historia en su $D e$ Disciplinis. Concluiremos con una de las varias reflexiones suyas que podríamos seleccionar: "Cree el autor que su principal obligación consiste en exaltar cuanto pueda al pueblo que describe; no pone sus ojos en la verdad, sino en la reputación de aquella nación...; los muy necios no entienden que eso no es escribir historia, sino defender la causa de ese pueblo; lo cual es tarea de abogado, no de historiador" (Putat rerum auctor id se tantum munus suscepisse, ut quantum possit, gentem illat evehat: non oculum ad veritatem adjicit, sed ad decus illius nationis... stulti non intelligunt hoc non esse historiam scribere, sed causam illius gentis agere, quod patroni est, non historici; II, VI, 4). 